\title{
A new Early Devonian (Emsian) arthrodire from the Northwest Territories, Canada, and its significance for paleogeographic reconstruction
}

\begin{tabular}{|r|l|}
\hline Journal: & Canadian Journal of Earth Sciences \\
\hline Manuscript ID & cjes-2017-0013.R1 \\
\hline Manuscript Type: & Article \\
\hline Date Submitted by the Author: & 06-Mar-2017 \\
\hline $\begin{array}{r}\text { Complete List of Authors: } \\
\text { Please Select from this Special } \\
\text { Issues list if applicable: }\end{array}$ & $\begin{array}{l}\text { Schultze, Hans-Peter; Natural History Museum } \\
\text { Cumbaa, Stephen L.; Canadian Museum of Nature }\end{array}$ \\
\hline Keyword: & $\begin{array}{l}\text { Lower Devonian, paleogeographic connections, Arctic Canada, arthrodires, } \\
\text { Heterostidae }\end{array}$ \\
\hline \multicolumn{2}{|c}{} \\
\hline
\end{tabular}

\section{SCHOLARONE" \\ Manuscripts}




\title{
Page 1
}

\section{A new Early Devonian (Emsian) arthrodire from the Northwest Terri- tories, Canada, and its significance for paleogeographic reconstruction}

\author{
Hans-Peter Schultze and Stephen L. Cumbaa
}

H.-P. Schultze, Natural History Museum, University of Kansas, 1345 Jayhawk Blvd., Lawrence, Kansas 66045-7561, USA E-mail: hp1937@ku.edu

S.L. Cumbaa (corresponding author), Canadian Museum of Nature, P.O. Box 3443, Station D, Ottawa, ON K1P 6P4, Canada E-mail: scumbaa@mus-nature.ca 


\title{
Page 2
}

\begin{abstract}
:
An heterostiid arthrodire, Herasmius dayi sp. nov., is described from upper Lower Devonian marine deposits of the Bear Rock Formation along the Anderson River, Northwest Territories, Canada. New elements described for the genus for the first time include the suborbital, submarginal (also new for the family Heterostiidae), the lateral shoulder girdle with posterior lateral, anterior dorso-lateral, and posterior dorso-lateral plates and possible infragnathal plate. We present a new reconstruction of the cranial region of Herasmius, previously known only from supposedly freshwater-shallow marine deposits of roughly the same age in the Wood Bay Group of Spitsbergen.
\end{abstract}

The late Early Devonian fishes that are common to the Arctic region of northwestern Canada and the island of Spitsbergen in the Svalbard archipelago of Norway, the porolepiform Heimenia and the arthrodire Herasmius described here, demonstrate the existence of a barrier-free paleogeographic connection between those continental blocks by the late Early Devonian. Comparison of the entire Anderson River vertebrate fauna with other boreal faunas of similar age indicates additional paleogeographic connections north of and around the Old Red Sandstone Continent to the Baltic region, central Europe, and even to the New Siberian Islands and South China, in contrast to most current published paleogeographical reconstructions.

\section{Résumé:}




\section{Page 3}

Un arthrodire hétérostiidé, Herasmius dayi sp. nov., est décrit à partir de dépôts marins de la partie supérieure du Dévonien inférieur provenant de la formation de Bear Rock, sur les berges de la rivière Anderson, Territoires-du-Nord-Ouest (Canada). De nouveaux éléments du squelette de ce genre sont décrits pour la première fois: les plaques suborbitaire et submarginale (une nouveauté également pour la famille Heterostiidae), la ceinture scapulaire latérale avec la plaque postéro-latérale, la plaque dorso-latérale antérieure, la plaque dorso-latérale postérieure et ce qui pourrait être la plaque infragnathale. Nous présentons une nouvelle reconstitution de la région crânienne de Herasmius, qu'on connaissait précédemment uniquement à partir de dépôts supposés d'eau douce ou marins peu profonds du groupe de Wood Bay au Spitsberg daté approximativement de la même période.

Les poissons de la fin du Dévonien inférieur qui sont communs à la région arctique du Nord-Ouest canadien et à l'île de Spitsberg dans l'archipel du Svalbard, en Norvège, c'est-à-dire le porolépiforme Heimenia et l'arthrodire Herasmius décrit-ici, démontrent l'existence d'une connexion paléogéographique ouverte entre ces blocs continentaux vers la fin du Dévonien inférieur. Une comparaison de l'ensemble de la faune de vertébrés fossiles de la rivière Anderson avec les autres faunes boréales d'âge similaire indique la présence d'autres connections paléogéographiques situées au nord et aux alentours du continent des Vieux Grès Rouges et menant à la région baltique, à l'Europe centrale et même aux îles de la Nouvelle-Sibérie et au sud de la Chine, contrairement à la plupart des reconstructions paléogéographiques publiées récemment. 


\section{Page 4}

Key words: Lower Devonian, paleogeographic connections, Arctic Canada, arthrodires, Heterostiidae

\section{Introduction}

In 1995 and 1997, two joint expeditions of personnel from the Museum für Naturkunde, Berlin, Germany, and the Canadian Museum of Nature, Ottawa, Canada, excavated a fossil fish locality discovered in 1958 by Standard Oil geologists in the Lower Devonian Bear Rock Formation, along the Anderson River of the western Canadian Arctic about 330 km east of Inuvik (Fig. 1). The 1997 expedition included J. Chorn and J. Harrison, formerly of the Natural History Museum, University of Kansas. The museum expeditions recovered many vertebrates, including complete specimens of the actinopterygian Dialipina (Schultze and Cumbaa 2001) and the small acanthodian, Melanoacanthus (Cumbaa and Schultze 2002). Porolepiforms, principally of the genus Heimenia (Ørvig 1969; Schultze 2000) are the most common vertebrate remains, especially the ubiquitous scales; the porolepiform Nasogaluakus is known by only one specimen (Schultze 2000). The dipnoan Melanognathus (Schultze 2001), represented by one skull roof and many lower jaws, is not as common. Only two small, isolated arthrodire fragments were recovered during the first two expeditions, from a locality about five kilometers downriver.

In 2008, a third joint expedition to the Anderson River locality included Stephen Cumbaa and Richard Day (Canadian Museum of Nature), Hans-Peter Schultze (Natural History Museum, University of Kansas) and John Chorn (Johnston County Community 


\section{Page 5}

College, Overland Park, Kansas). Substantial arthrodire remains were discovered. These most recently discovered arthrodire specimens are described here.

\section{Geology and Stratigraphy}

In 2001, Cumbaa and Schultze (2002, p. 1457) described the locality on Anderson River as "two $150 \mathrm{~m}$ long lenses about $1 \mathrm{~km}$ apart that are bisected by the river". In 2008, we realized that the two lenses belong to the same horizon of limestones and dolomites, which occurs along the river with considerable variation in the number of fish fossils along the exposure. The "two lenses" (AND-3/3A and AND-4/4A, Fig. 1) represent two concentrations of fossil fishes within the same horizon. There are differences in concentration and content even from one side of the river to the other. Complete specimens of Dialipina, the acanthodian Melanoacanthus, and the head of the porolepiform Nasogaluakus, as well as remains of the porolepiform Heimenia were discovered at locality AND-3A on the right bank of the river. Numerous remains of Heimenia were found on the left bank at locality AND-3 and on a small rocky islet in the river a few meters offshore from the locality in 1995. Dialipina scales and Melanognathus jaws were found in the shoreline deposits at locality AND-3. The arthrodires described here were discovered in 2008 in one deeper in situ layer at locality AND-3, except for one bone recovered from a loose block at the downstream end of AND-3A.The arthrodire layer is approximately half a meter below the AND-3 layers containing Dialipina scales, Melanognathus jaws and Heimenia remains.

The second concentration or "lens" (AND-4) lies $1 \mathrm{~km}$ upriver from locality AND3 near our 2008 campsite. The locality AND-4 on the right side of the river produced 


\section{Page 6}

parts of the porolepiform Heimenia, the head and jaws of the dipnoan Melanognathus and scales of Dialipina. Sarcopterygian scales were found on the left bank (locality AND4A).

Two additional localities (AND-1 and -5) were discovered in 1995, about $7 \mathrm{~km}$ down the river. These localities, small limestone outcroppings, produced only a few fragments of bone. Two isolated fragments of ornamented placoderm bone were found at AND-5, and represent one or more indeterminate arthrodire species.

All the fish remains occur in the lower to lower-middle part of the Bear Rock Formation, which bridges the Lower/Middle Devonian boundary (Balkwill and Yorath 1970). The large ostracode Moelleritia canadensis, indicative of an Emsian age (Norris 1997), is ubiquitous in the vertebrate-bearing strata; thus we estimate late Early Devonian (Emsian) in age (for detailed discussion of the age see Cumbaa and Schultze 2002) for the fish remains.

\section{Material and Methods}

The arthrodire remains described here were collected in 2008 and are deposited in the Canadian Museum of Nature, Ottawa, Ontario, Canada (CMN) except for one specimen collected in 1995 at locality AND-5, now in the collection of the Museum für Naturkunde, Berlin, Germany (MB).

The specimens were taken in plaster jackets from the field, and were prepared at the Canadian Museum of Nature in Ottawa by Alan McDonald using a pin vise and needle and a PaleoTools Micro Jack. He also prepared Figure 1 (locality map) and Figure 13 (paleogeographic map). The specimens were drawn with a camera lucida on Wild M4 


\section{Page 7}

and Leitz M8 microscopes by H.-P. Schultze. The drawings comprising Figures 3B-8B and 12B were transferred in ink by the late Jörg-Peter Mendau, Berlin, and those for Figures 2A, 2B, 9, 10A and 10B were digitally inked by Susan Laurie-Bourque, Ottawa. Photographs for figures 3A, 4A, 5A, 7A, 8A and 13A were taken by S. L. Cumbaa using a Canon EOS 7D digital SLR and EF 24-105 F/4L IS USM lens; those for figures 6A and 11 were taken by O. Sanisidro, Museum of Natural History, Lawrence, Kansas. The photo used as Figure 4C was taken in the field by John Chorn using a Nikon D-90 with AF-S Micro Nikkor 60mm f/2.8G ED lens.

We follow Denison (1978, p. 123-124) in the terminology and the abbreviations of bones and sensory lines.

\section{Systematic paleontology}

Most of the collected arthrodire remains belong to one species, Herasmius dayi n. sp. At least two other arthrodire species are represented by single bones.

Class Placodermi M’Coy, 1848

Order Arthrodira Woodward, 1891

Suborder Brachythoraci Gross, 1932

Family Heterostiidae Jaekel, 1903

DIAGNOSIS (Zhu et al. 2016, p. 4, emended): Moderately to very large arthrodires with the cranial and trunk shields broad and dorso-ventrally compressed. Skull roof narrows anteriad, and the postero-lateral corners of the skull roof are in line with the foremost 


\section{Page 8}

point of the nuchal gap. Small orbits antero-dorsally positioned. Rostral plate comparatively short rostro-caudad, pineal plate narrow. The condyles of the craniothoracic articulation are strongly developed, but not transversely elongated. The lateral wall of the thoracic armor is much reduced; the anterior lateral plate is fused with the anterior dorso-lateral plate and forms an elongated, rod-like far anterior reaching process. There is a prominent posterior carinal process of the ventral keel on the median dorsal plate.

REMARKS: Three genera, Heterostius Asmuß, 1856, Herasmius Ørvig, 1969 and Yinostius Wang et Wang, 1984, comprise the family Heterostiidae. The Heterostiidae are placed at the base of the brachythoracan arthrodires by Young (1981) and Denison (1984), whereas Heterostius appears within derived Brachythoraci, the Eubrachythoraci, in cladograms of arthrodires published by Zhu and Zhu (2013: Heterostius sister of the three included Dunkleosteus species) and Zhu et al. (2015: (((Heterostius + Yinostius) Dunkleosteus amblyodoratus) Dunkleosteus terrelli + raveri)). The main characters for the placement within higher brachythoracans are the pronounced postero-lateral corner of the skull roof, and the posterior carinal process of the median dorsal plate. Zhu and Zhu (2013) cited six synapomorphies of Dunkleosteus and Heterostius. Zhu et al. (2016) placed one species of Dunkleosteus, D. amblyodoratus, as sister of Heterostius + Yinostius based on fusion of the anterior lateral plate and the anterior dorso-lateral plate, a character of Heterostiidae; nevertheless, these plates are unknown in Dunkleosteus amblyodoratus (Carr and Hlavin 2010). The latter species is known only by nuchal and paranuchal plates and the parasphenoid. There is a time gap between the first appearance 


\section{Page 9}

of the Early/early Middle Devonian Heterostiidae and the Late Devonian Dunkleosteidae; Yinostius is of Emsian age, as is Herasmius. We will return to this placement later.

Genus Herasmius Ørvig, 1969

DIAGNOSIS (Ørvig 1969, p. 278 emended): A brachythoracid arthrodire genus belonging to the family Heterostiidae, reaching moderate size (for that family). Preorbital plates short rostro-caudad and broad compared to the other two genera. Central plate proportionally large, extending backwards laterally to the nuchal plate for about half the rostrocaudal length of that plate. Paranuchal plate proportionally short and wide. Nuchal plate with tripartite anterior portion comprising a broad middle extension bordered by two short lateral processes.

REMARKS: The length/width relationship of the head shield (Ørvig 1969, p. 278) is not accepted here as a character because the middle part of the skull is missing. In addition the specimen is distorted, so that the width of the nuchal is a tectonic feature (Fig. 2A). Tectonic deformation may also be the reason that the bones in the holotype appear thin. Herasmius is distinct from the other two genera in the family by the shape of the central plate and their posterocaudal extension along the nuchal plate, and the anterior broad process of the nuchal plate.

TYPE SPECIES: Herasmius granulatus Ørvig, 1969 


\section{Page 10}

DIAGNOSIS (Ørvig 1969, p. 278/279 emended): Dermal bones showing an ornamentation of very fine, closely-set tubercles. Wide middle part of the tripartite anterior nuchal plate (about 2 times as wide as long rostrocaudad); preorbital plates squarish and a little wider than long; anterior part of central plates squarish.

REMARKS: As part of our comparison, we tried to eliminate the tectonic distortion and to restore the skull roof of Herasmius granulatus on the basis of the new species from Anderson River, which was recovered largely complete and relatively undistorted. The nuchal plate of $H$. dayi n. sp. is taken as the focal point. In addition the length of the central plates is equalized with the length of the central plate of $H$. dayi n. sp.. The result is a longer and less wide skull roof (Fig. 2B) with a width/length ratio of about 1.5 similar to Heterostius. Yinostius and H. dayi n. sp. are a little less wide (width/length ratio 1.3 to $1.4)$.

TYPE LOCALITY: Valley Jakobsendalen, NW part of Andrée Land, Spitsbergen.

GEOLOGICAL AGE: Verdalen member of Stjørdalen Formation, Wood Bay Series, Lower/Middle Devonian (after Birkenmajer 1964 and Piepjohn 1997: Emsian; after Ørvig 1969 and Blieck et al. 1987: at the Lower/Middle Devonian boundary).

Herasmius dayi sp. nov. (Figs. 3-9)

ZooBank No: urn:lsid:zoobank.org:pub:887766C5-5AEB-491E-B866-35CF84BA7C42 
Page 11

HOLOTYPE: CMN FV 54694 (posterior head shield + anterior shoulder girdle = field number AND-3 - 34) (Fig. 3).

REFERRED SPECIMENS: CMN FV 54663a, b (three bones: left suborbital plate, infragnathal + postorbital plate with tubercles and infraorbital sensory line $=$ AND-3 -3 , Fig. 7); CMN FV 54664 (nuchal plate = AND-3 - 4); CMN FV 54665 (left suborbital plate = AND-3 - 5; Fig. 6); CMN FV 54683 (part of median dorsal plate = AND-3 - 23); CMN FV 54697a, b (piece of anterior lateral plate = AND-3 - 37); CMN FV 54699 (median dorsal, right anterior dorso-lateral + anterior lateral, and left central plates $=$ AND-3 - 39; Fig. 4); CMN FV 54700a (left submarginal plate and piece of unidentified bone [probably the right margin of a median dorsal plate] = AND-3 - 40a; Fig. 5); CMN FV $54700 \mathrm{~b}$ (left anterior lateral and posterior lateral plates = AND-3 - 40b; Fig. 8); CMN FV 54720 (part of median dorsal plate = AND-3 - 60); CMN FV 54737a, b (median dorsal plate broken in different pieces preserved in one block $=$ AND-3 -77 ).

LOCALITY: Standard Oil Company locality AR.25.58 at $68^{\circ} 11^{\prime} 06^{\prime \prime}$ N Latitude, $125^{\circ} 49^{\prime} 72^{\prime \prime} \mathrm{W}$ Longitude, Anderson River in the western Canadian Arctic, about $330 \mathrm{~km}$ east of Inuvik, N.W.T., Canada.

AGE AND GEOLOGICAL FORMATION: Early Devonian (Emsian); lower part of Bear Rock Formation. 


\section{Page 12}

ETYMOLOGY: Named to honor the special efforts by Richard Day toward the excavation of the arthrodires at locality AND-3, as well as his roles as camp manager, chief cook, logistics specialist and expedition member in 1995, 1997, and 2008.

DIAGNOSIS: Ornamentation of tubercles variable in size, from large to small tubercles changing on the same bone. Wide middle part of the tripartite anterior nuchal plate (width 1.5 times its length, thus narrower than in H. granulatus). Central plates with anterior and posterior digitate sutures.

DESCRIPTION: The anterior part of the holotype (Fig. 3) is weathered away, and the posterior border represents a saw cut in front of the outcrop wall. It is the skull of a brachythoracid arthrodire with nuchal, paranuchal, central, marginal, postmarginal, and submarginal plates, and remains of the left postorbital plate. The shoulder girdle shows the anterior half of the median dorsal plate, the anterior dorso-lateral plate with anterior lateral plate, the left posterior dorso-lateral and the left posterior lateral plate.

The nuchal plate has a width/length ratio of 1.4, and the median part of the tripartite anterior portion a width/length ratio of about 1.3. The anteriad-directed lateral processes of the tripartite anterior portion are short; the median anterior portion is broad with a digitate anterior suture. The posterior halves of the central plates are preserved; they reach postero-laterad over half the length along the nuchal plate and connect in a zigzag suture with the paranuchal plates. Both central plates have a posteriad-directed medial process, which forms the lateral margin of the tripartite anterior portion of the nuchal plate.

The rounded paranuchal plates are broad and short. The groove of the main lateral 


\section{Page 13}

line passes over the paranuchal from the marginal plate to the articulation with the shoulder girdle. On the left paranuchal plate the main lateral line is split; the anterior groove stops in the posterior third of the bone where it approaches the groove of the posterior part of the main lateral line, which continues as the groove of the posterior pit line towards the center of the paranuchal bypassing the anterior part of the main lateral line.

The marginal plates are long and narrow, about 3 times longer than wide. On the marginal plates, the groove of the otic branch of the infraorbital line splits in to the continuing main lateral line and the postero-ventrad directed postmarginal sensory line. The suture of the marginal plate with the paranuchal plate forms a "tongue" towards the paranuchal on the left side, but not on the right side. The right postmarginal plate is displaced from the contact with the marginal plate, whereas on the left side the suture between both plates is difficult to follow. A submarginal plate lies lateral to the marginal and postmarginal plates. The right one is preserved turned in to the skull plane, whereas the left one is pushed against the skull so that its shape is not visible. The right submarginal plate has a long anteriad directed shaft and a posterior short part oblique to it, the foot. The boot-like shape of the submarginal plate is unusual within arthrodires.

Single plates were collected in addition to the holotype. These are the nuchal, central, suborbital and submarginal plates. Specimen CMN FV 54664 represents a large (1.6 times the size of the nuchal plate of the holotype) nuchal plate lacking the posterior margin. It shows the broad median part with its anterior digitate margin and the small anteriad-directed lateral processes of the tripartite anterior portion. Large and small tubercles cover the surface. A broad band of small tubercles runs antero-posteriad in the middle of the nuchal. 


\section{Page 14}

A nearly complete left central plate (Fig. 4) appeared when the right part of the median dorsal plate was lifted on specimen CMN FV 54699. In addition the right anterolateral and the anterior dorso-lateral plates became visible. The central plate has the posterior zigzag suture like the central plates of the holotype and shows the medial process, which borders laterally the tripartite anterior portion of the nuchal; in addition the anterior part of the central is preserved with a digitate anterior border and the grooves of two sensory lines, the supraorbital and the central lateral line. A weak groove runs of the posterior pit line runs postero-laterad on the postero-lateral extension of the central plate towards the paranuchal plate. The suture with the postorbital plate is straight.

A separate left submarginal plate (Fig. 5) appears on specimen CMN FV 54700a. It shows the same boot-like shape as the right submarginal plate on the holotype; it is more arched towards the marginal and postmarginal plates than the submarginal on the holotype. We did not find any submarginal plate of similar shape in the literature, and the submarginal plate is not known for any of the three heterostiid genera. Nevertheless an identically- shaped bone exists in the Estonian material of Heterostius ingens (personal communication by E. Mark-Kurik). Thus the boot-like shape of the submarginal plate seems to be unique for heterostiids.

There are two bones seen only from their inside surfaces. We interpret them as left suborbital plates (Figs. 6, 7) by comparison with the suborbital plate of Heterostius (Heintz 1930, fig. 2). The isolated one (CMN FV 54665, Fig. 6) has a posterior part with irregular margins; it narrows anteriad and arches antero-dorsad so that it surrounds partially the orbit (see reconstruction, Fig. 9). The second left suborbital plate is associated with two plates on specimen CMN FV 54663 (Fig. 7); it is 1.5 times larger 
than CMN FV 54665 and has a rounded posterior dorsal margin compared to the bayed posterior dorsal margin of the smaller suborbital plate.

The elongated straight and flat bone (Fig. 7) may represent an infragnathal. The reason for such an interpretation is the ridge parallel to the straight margin of the bone. The bone looks quite different from other infragnathals in arthrodires. Infragnathals are not known in heterostiids. The tuberculated plate with the groove of a sensory line may be part of the postorbital plate judging from the arched course of the sensory line groove. This is the postorbital part of the infraorbital sensory line, if the interpretation of the bone as the postorbital plate is correct. The tuberculated process could be compared with the process on the right postorbital in the reconstruction of Heterostius ingens (Heintz 1930, fig. 2). In front of the process lies a long area overlapped by the preorbital. That would mean that the postorbital plate does not reach the orbit, and the preorbital plate is broader than in both reconstructions of Herasmius, that by Ørvig (1969) and the one presented here (Fig. 9), and forms the posterior margin of the orbit. Nevertheless, we are not certain of the identification.

In the holotype, the partially preserved shoulder girdle with median dorsal plate, anterior dorso-lateral that extends as far forward as the anterior lateral plate, with posterior dorso-lateral and posterior lateral plates follows behind the skull roof (Fig. 3). The anterior part of the median dorsal is preserved in the holotype only. A short anteromedian process reaches in to the nuchal gap. The median dorsal possesses laterally an invagination, into which the anterior dorso-lateral plate fits. The anterior dorso-lateral plate reaches around the antero-lateral extension of the median dorsal plate forming a short pre-median dorsal process. The median dorsal plate possesses a median keel on its 
Page 16

inner side that extends posteriad reaching the cranial process (Fig. 3). The image of the median dorsal plate of specimen CMN FV 54699 (Fig. 4C) taken in the field shows the median dorsal plate best, as it suffered somewhat during removal and transport (Figs. 4A, B). The short antero-median process is not known from Heterostius. The invagination of the lateral side and posteriad reaching cranial process can be clearly seen.

Two anterior dorso-lateral plates (Figs. 4, 8) were discovered in addition to the ones on the holotype. The right anterior dorso-lateral on CMN FV 54699 (Fig. 4) is preserved together with its fused anterior lateral plate. In contrast the isolated left anterior dorso-lateral plate (CMN FV 54700b) is associated with the posterior dorso-lateral plate, but it lacks the anterior lateral plate (Fig. 8); the latter is broken off at the antero-ventral corner of the anterior dorso-lateral plate. The middle tuberculated portion of the external surface of the anterior dorso-lateral plate is bordered dorsally by the area overlapped by the antero-lateral corner of the median dorsal plate and ventrally by the area overlapped by the posterior lateral plate. The anterior dorso-lateral plate extends as a triangular shape on to the posterior dorso-lateral plate. The posterior border of the posterior dorso-lateral plate is broken; nevertheless the plate should not reach much further caudad. The posterior dorso-lateral plate has only a small exposed area; most of the plate is covered by the median dorsal and the anterior dorso-lateral plates, and some of the ventral part by the posterior lateral plate. The groove of the main lateral line runs along the lower part of the anterior dorso-lateral and posterior dorso-lateral plates; it continues from the anterior dorso-lateral plate to the posterior dorso-lateral plate at the point where the suture between the plates reaches anteriad. A narrow strip, the pre-median dorsal process, borders anteriorly the area overlapped by the median dorsal plate; it surrounds the antero-lateral 


\section{Page 17}

extension of the median dorsal plate. In front the short and strong condyle, which articulates with the paranuchal plate, points upwards. Deep depressions border the condyle posteriorly and antero-ventrally. The narrow antero-ventral groove separates the condyle from the subglenoid fossa. The subglenoid fossa has a grooved (fan shaped) lateral surface and a small dorsal area.

A large overlapped area lies below the tuberculated area of the anterior dorsolateral plate; that could be the overlap area of the posterior lateral plate, which would reach forward past the area of articulation. Gross (1933, fig. 9 A, F) figured and described a groove in the same area in Heterostius; Abel (1927, figs. 1, 2A) reproduced unpublished figures of Heterostius by Jaekel, where the deepened region is interpreted as attachment for muscles. On the holotype of Herasmius dayi n. sp., an elongated bone, the posterior lateral plate, lies in this area on the left side of the specimen (Fig. 3).

The second isolated bone, a right anterior dorso-lateral plate together with its anterior lateral plate, appeared when parts of the median dorsal plate were removed on specimen CMN FV 54699 (Fig. 4A, B). The area overlapped by the median dorsal plate is preserved with the narrow strip surrounding the antero-lateral extension of the median dorsal plate, the pre-median dorsal process. In front of the narrow strip, the condyle of the exoskeletal articulation is visible. A rounded narrow anterior lateral plate extends in front of the anterior dorso-lateral plate.

RECONSTRUCTION: The reconstruction of Herasmius dayi n. sp. (Fig. 9) is based mainly on the holotype. The isolated central plate (Fig. 4) allowed the extension of the skull roof further anteriad. Pre- and postorbital plates are adapted from the reconstruction 


\section{Page 18}

of Herasmius granulatus by Ørvig (1969), with the addition of the suborbital plates after the Heterostius reconstruction by Heintz (1930). The anterior shape of the central plate leaves a wider space for the pineal plate than in Herasmius granulatus and Heterostius ingens. The position of the submarginal corresponds to its appearance in the holotype. It is not certain that it covered the antero-lateral plate in dorsal view. Placing a submarginal in Heintz's reconstruction of Heterostius ingens would cover the antero-lateral plate partly. The shoulder girdle is well preserved in the holotype; the posterior part of the median dorsal plate is added from specimen CMN FV 54699 (Fig. 4).

COMPARISON: Ørvig (1969) described the new heterostiid genus, Herasmius, from the Verdalen member of Stjørdalen Formation, at the boundary of Lower to Middle Devonian of Spitsbergen and compared it with Heterostius from the Middle Devonian (Eifelian) Aruküla beds of Estonia. Both genera have in common the anterior position of small orbits and the arrangement and shape of the preorbital, postorbital, marginal and paranuchal plates and their sensory line system in the cranial roof, as well as a long antero-lateral fused to the anterior dorso-lateral plate and a pronounced posterior cranial process on the median dorsal plate in the shoulder girdle. The shape of the suborbital plate is also very similar. After Ørvig (1969), the main difference between both genera is the width/length ratio of the skull roof. In Herasmius the skull length is supposedly $70 \%$ of skull width whereas in Heterostius it is $54 \%$. Nevertheless there are problems with these ratios as shown above. The type and only specimen of Herasmius granulatus is tectonically deformed in lateral direction, so that the length/width ratios are misleading. The nuchal is not as broad as in Ørvig's 1969 reconstruction (fig. 3A; here Fig. 2A). In addition, the 


\section{Page 19}

anterior portion of the skull roof is separated from the left posterior part, so that the length of the skull roof is not measurable. Proportions given by Ørvig (1969) are therefore not verifiable and not usable to argue that the specimens of Vestspitsbergen belong to a different genus than Heterostius. Our reconstruction of Ørvig's form from Vestspitsbergen, Herasmius granulatus (Fig. 2B), results in a length/width ratio of the skull roof of $67 \%$, the same as that of Heterostius ingens. Herasmius dayi n. sp. gives a length/width ratio of $74 \%$, similar to that of Yinostius major (75\%). Thus the length/width ratio cannot be used to distinguish the three genera.

Comparing Heterostius ingens Asmuß, 1856, with our new reconstruction of Herasmius granulatus shows that the length/width proportions of the skull roof are similar; even the nuchal plate has a similar length/width ratio. The difference between the two species is the configuration of the anterior portion of the nuchal plate. The median process reaches rostrad with digitate sutures with the central plates left and right of a median narrow anterior spike (Fig. 10A) in Heterostius ingens, whereas the median process is tripartite in Herasmius granulatus and H. dayi n. sp., with a broad median portion accompanied by two short lateral processes. The second difference between both genera is the length and relation to the nuchal plate of the central plates. The central plates reach farther posteriad along the nuchal plate in Herasmius than in Heterostius. In contrast the distance is short in Heterostius, thus the paranuchal is shorter and broader in Herasmius.

The shapes of the triangular nuchal plate and of the central plates of the third genus, Yinostius (Fig. 10B), of the Heterostiidae are very distinct from those of the same bones of the two other genera of the family. We use here the reconstruction of Yinostius 
Page 20

by Wang and Wang (1984, fig. 1C; here Fig. 10B) with the postero-lateral corners not as far back as in Zhu et al. (2015, figs. 6D, 7C, 8A), as the photographs and figure 5 in Zhu et al. (2015) show a position as in Wang and Wang (1984, fig. 1C). The triangular nuchal plate of Yinostius is very distinct from that of the other two genera; it lacks a tripartite anterior portion. The central plates reach only a little back from the tip of the nuchal plate so that the paranuchal plates are very long antero-medial to postero-lateral. The central plates are very short and the preorbitals narrow in comparison to the other two genera.

The median dorsal plate of Herasmius (Ørvig 1969, fig. 4D; here Figs. 3, 9) possesses a short anterior process extending to the space between the nuchal and median dorsal plates. Such a process does not occur in Heterostius and Yinostius. The posterior cranial process is known in all three genera; the reconstruction of the median dorsal of $H$. granulatus (Ørvig 1969, fig. 4C) does not show the process, as this part of median dorsal is not preserved.

We place the arthrodire from Anderson River in Ørvig's genus Herasmius based on the shape of the anterior portion of the nuchal plate and the posterior extension of the central plates. The new species, Herasmius dayi, is distinct from H. granulatus in the anterior shape of the central plates, which are squarish in H. granulatus but narrower and with a digitate suture with the preorbital plate in $H$. dayi n. sp.. The pineal plate appears to be wider in H. dayi n. sp.. It separates the anterior parts of the central plates judging from their shape; that is not the case in H. granulatus, Heterostius and Yinostius. The middle part of the anterior tripartite portion of the nuchal plate is wider in $\mathrm{H}$. granulatus (two times wider than long) than in $H$. dayi n. sp. (1.5 times wider than long). 


\section{Page 21}

The description of Herasmius dayi n. sp. adds to our knowledge of the heterostiids in the following ways:

1. Neither a description nor the presence of a submarginal has been published from heterostiids. The boot shaped submarginal occurs in position in the holotype of $H$. dayi n. sp.. This is a shape quite different from the elongate submarginal in other arthrodires; however, a submarginal of Heterostius in Estonian material is said to have the same shape (E. Mark-Kurik, personal communication).

2. Infragnathals are not known in heterostiids. The bone interpreted as such here for $H$. dayi n. sp. is different from those of other arthrodires, which are not flat like this bone. There may be some similarities to Angarichthys (Heintz 1934, fig. 28I), an homosteid. 3. A small posterior lateral plate is known in Heterostius (Fig. 10A), but is lacking in Homostius after Heintz (1934). In contrast to Heterostius, the posterior lateral plate in Herasmius is elongated.

4. The suborbital is new for the genus Herasmius. It has a shape similar to that in Heterostius.

\section{OTHER ARTHRODIRE MATERIAL:}

Two placoderm bones from locality AND-3 do not belong to the genus Herasmius, a plate with small tubercles CMN FV 54691 (AND-3 - 31; Fig. 11) and a right suborbital plate CMN FV 54827 (AND-3A - 47; Fig. 12). The plate with small tubercles represents a central plate cf. Bryantolepis, a sister taxon to Phlyctaenoidei (included in the paraphyletic "Actinolepidoidei" by Dupret et al. 2009 and Elliott and Carr 2010). The groove for the central lateral line and pit lines are missing. The anterior me- 
Page 22

dial corner of the plate is broken off. Bryantolepids are known from Lower Devonian rocks.

The right suborbital plate CMN FV 54827 (Fig. 12) has a dorsal margin invaginated slightly for the postorbital plate; the posterior margin is straight with a narrow overlap area for the postsuborbital plate; its ventro-posterior corner is broken off (or cut during field collection). The ventral margin shows a broad ventral extension. The anterior process is massive with a dorsal extension as in Dunkleosteus. The anterior margin above the anterior process is slightly bowed towards anteriad. The vertical part of the infraorbital sensory canal is preserved, but neither its anterior extension nor the supraoral canal. The squarish shape of the suborbital plate is otherwise found only in Dunkleosteus within arthrodires (Heintz 1932, fig. 21); it lacks the ventral tongue-shape extension of the anterior process of Dunkleosteus, but possesses the dorsal protuberance of the anterior process (labeled "a" in Heintz 1932, fig. 21). The ventral margin is not straight as in Dunkleosteus but has a similar broad ventral extension. We place the specimen within the dunkleosteids. That placement would extend the temporal extent of the dunkleosteids to the Early Devonian and close the time gap between Early Devonian Heterostiidae and Late Devonian Dunkleosteidae see above).

We collected scrappy arthrodiran material (MB f.19149) in 1995 at locality AND-5. These are two unidentifiable pieces of bone with large tubercles.

\section{Paleogeography}

\section{Genera shared with other Emsian localities}


Page 23

The arthrodire Herasmius dayi n.sp. is the most recent addition to the small but relatively diverse Early Devonian (Emsian) fauna of Anderson River, NWT, Canada. The new species shows closest similarities to Herasmius granulatus Ørvig (1969) from Vestspitsbergen (Verdalen Member, Stjørdalen Formation, Wood Bay Group) in the Svalbard archipelago, also of Emsian age (Ørvig 1969; Clément 2001a,b). The two localities also share a second genus, the porolepiform Heimenia (Ørvig 1969; Clément 2001b; Mondéjar-Fernàndez and Clément 2012).

Herasmius is so far restricted to the Anderson River and to Spitsbergen, whereas Heimenia has a wider distribution in the Lower Devonian, from Spitsbergen to the Baltic region (Lyarskaya 1981, Clément 2001a), central Europe (Holy Cross Mountains, Poland [Ørvig 1969], and the Klerf Beds of the Eifel, Rhenish Slate Massif, Germany [Jessen 1989: early Emsian]), as well as to China (Wang 1986: Givetian; Zhu 2000; Zhao and Zhu 2010: late Emsian). Thanh and Janvier (1987) list Heimenia-like sarcopterygian scales from the Lower Devonian (Lochkovian) of Vietnam.

A third Anderson River vertebrate genus is found not in Spitsbergen but in Lower Devonian strata elsewhere. The actinopterygian Dialipina salgueiroensis was first described from Anderson River (Schultze 1968; Schultze and Cumbaa 2001); the genus Dialipina has also been reported from Lower Devonian deposits (Lochkovian) on Kotelny Island, New Siberian Islands, Russia (Mark-Kurik 1974; Schultze 1977), and from South China (lower Emsian; Zhao and Zhu 2010). Schultze (1992) also reported Dialipina from the Kotui Basin, Siberia (Lochkovian and Pragian). The Lochkovian Kotui Basin fossil skulls have since been re-described by Giles et al. (2015) as a new genus and species, Janusiscus schultzei, which is interpreted as a basal gnathostome. 


\section{Page 24}

Table 1 lists Lower Devonian localities that share vertebrate genera with the Anderson River localities.

\section{Paleogeographic connections and possible dispersal routes}

The shared presence of two genera of large, active fish (Herasmius and Heimenia) at Anderson River, NWT, Canada, and on Spitsbergen in the Svalbard archipelago indicates a viable open-water connection between the two areas by late Early Devonian. The presence of Heimenia in the Lower Devonian of the Baltic region, central Europe, south China and possibly Vietnam suggests widespread distribution of Heimenia by the Early Devonian. Similarly, occurrences of a third Anderson River fish genus, the much smaller Dialipina, indicate a very lengthy marine connection by the late Early Devonian between the Canadian Arctic, Siberia, and South China.

\section{$\underline{\text { Paleoenvironment }}$}

In discussing paleogeographic connections between the three genera and the localities in Table 1, we focus on marine links. The Anderson River fauna is unquestionably shallow water marine, with ostracodes, eurypterids, other invertebrates and fishes together in a limestone and dolomite matrix consistent with its mapped description within the marine Bear Rock Formation (Balkwill and Yorath, 1970; Cumbaa and Schultze 2002).

The Herasmius and Heimenia locality in Spitsbergen (Wood Bay Formation, Verdalen Member) has traditionally been considered to be of continental origin (Pernègre and Blieck 2016). The Verdalen Member is primarily composed of carbonate sediments but many of the fossils have been found in terrigenous material. However, the occur- 
Page 25

rence of lingulids and other usually marine fossils lead Goujet (1984) and others (Blieck 1984; Goujet and Emig 1985; Blieck and Janvier 1999) to the conclusion that the paleoenvironment was semi-continental - fjords and estuaries fed by rivers (Pernègre and Blieck 2016). Blomeier et al. (2003) examined the sedimentation of the Wood Bay Formation and concluded that in the upper part of the Verdalen Member, the late Early Devonian environment was a broad lake plain which developed into a marginal marine coastal plain with open connections to the sea, influenced by recurrent sea-level highstands. These studies, while differing in specific interpretation, indicate that the depositional environment of the late Early Devonian Herasmius and Heimenia fauna in northern Spitsbergen was intermittently or more permanently marginal marine.

Similarly, the source of deposition at localities in the Baltic region has been interpreted as continental, based in part on the clastic sedimentation. Others (Mark-Kurik $1991 a$; Kuršs 1986, 1992) considered them as shallow marine. Kuršs (1992) noted that near the end of the Early Devonian there was a shift from marine carbonate to siliciclastic deposition, most likely from the Baltic Shield and/or the Caledonian foreland.

The paleoenvironment of Heimenia from the Klerf Beds of the Eifel, Rhenish Slate Massif of Germany is not entirely clear, but a recent study indicates that the area in the Early Devonian included marine, brackish, and terrestrial settings (Wehrmann et al. 2005). Porolepidid porolepiforms are considered as fully marine or near shore inhabitants (Clément 2001a; Mondéjar-Fernández and Clément 2012). The fish-bearing sequences in the Alken quarry are interpreted as representing a nearshore marine environment. Intertidal, shallow water habitat with reduced salinity persisted over a lengthy pe- 


\section{Page 26}

riod in the Early Devonian, with the basin characterized by balanced subsidence, rapid sedimentation and fluctuating sea levels (Wehrmann et al. 2005).

Localities 5 and 6 in Table 1, Kotelny Island (Siberia/New Siberian terrane) and southwest China (South China block), are clearly of marine origin. Schultze (1977, 1982) cited a marine environment for the Kotelny Island, Siberia Dialipina locality. The Yujiang Assemblage from Sichuan, China, which includes Dialipina, is associated with conodonts, corals, brachiopods and bivalves indicating a neritic shelf facies (Zhao and Zhu 2010). The Chuandong Assemblage from Yunnan, China, which includes Heimenia, had a shelf facies depositional environment (Zhao and Zhu 2010).

In conclusion, the paleoenvironmental interpretations of the localities where $\mathrm{He}$ rasmius, Heimenia and Dialipina occur place the genera in marine to lagoonal biota but always with a connection to the marine realm.

\section{$\underline{\text { Dispersal routes }}$}

Plotting possible dispersal routes for these genera can be seen as a work in progress. The early occurrences of ?Heimenia in the Lochkovian of Vietnam and of Dialipi$n a$ in the Lochkovian and Pragian of Siberia could indicate a migration route from the east and northeast to Spitsbergen and Anderson River. A connection between the Canadian Arctic north of and around the Old Red continent to Spitsbergen, Siberia, the Baltic region (as in Blieck and Cloutier 2000, fig. 2A; Mark-Kurik et al. 2013 for the Lochkovian; Pernègre and Blieck 2016 for Pragian and Emsian) and to central Europe is necessary to explain the faunal similarities. Lukševičs et al. (2010) discussed paleozoogeographical connections of the Devonian vertebrates of Baltica. Blieck and Janvier (1999), building on Young (1990), linked the occurrences in the Canadian Arctic, Spitsbergen and Siberia 


\section{Page 27}

within an Arctic faunal province and the occurrences in the Baltic region, Poland and the Old Red continent to a North Atlantic faunal province (see also Blieck 2009, fig. 10). Zhao and Zhu (2010) discussed possible dispersal routes within the context of five major vertebrate faunal provinces for the Early Devonian, highlighting three possible routes to accommodate the evidence from China, based on two different paleogeographic reconstructions.

There have been significant changes in the understanding of Paleozoic paleogeography since the late 1980 s, particularly the movement of individual blocks and terranes, the timing of collisions as larger continental masses were formed, and their geographic positions. For example, the latitudinal position of the locality at Anderson River, NWT $\left(\sim 68^{\circ} \mathrm{N}\right.$ currently) would have an estimated latitudinal position in the Early Devonian near $30^{\circ} \mathrm{N}$ (Ziegler 1981), approximately $5^{\circ}-10^{\circ} \mathrm{N}$ (Scotese and McKerrow 1990; Kent and Van der Loo 1990), or as roughly $5^{\circ}-8^{\circ} \mathrm{S}$ latitude in the current decade (Lawver et al. 2011; Golonka and Gaweda 2012; Torsvik and Cocks 2013; Domeier and Torsvik 2014). Witzke (1990) was an exception to the conclusions in the majority of earlier papers in estimating more southerly positions for Laurentia + Baltica (now Laurussia). Here we use the more recent paleogeographic and plate tectonic papers (Lawver et al. 2011; Golonka and Gaweda 2012; Torsvik and Cocks 2013; Domeier and Torsvik 2014) to estimate the paleolatitude for the Anderson River locality in the Emsian as roughly $5^{\circ}-8^{\circ} \mathrm{S}$ latitude.

Figure 13 indicates the position of the Lower Devonian localities that share genera with the Anderson River locality on a paleogeographic reconstruction that approximates the position of paleocontinents and terranes in the Early Devonian. Young (1990) plotted many Devonian vertebrate occurrences, including most of those listed here in Ta- 
Page 28

ble 1, on a base map by Scotese (1986). He did not include the Anderson River locality. Young's base map is an Early Devonian (Lochkovian) projection, but the localities include those from the entire Devonian.

Many published maps of Early Devonian paleogeography and paleobiogeography show that potential faunal dispersal routes between some of the localities in Table 1 could have been blocked by the coalescence of land masses in the late Early Devonian. However, most show more open marine connections in the Late Silurian and earliest Devonian (e.g., Johnson et al. 2000; Golonka et al. 2003; Lawver et al 2011; Torsvik and Cocks 2013), and it seems likely that the presence of at least some of the genera recognized from the late Early Devonian localities in Table 1 is the result of earlier connections.

No landmass barriers are apparent in the late Early Devonian reconstructions (Figs. 13) between the New Siberian Islands terrane and the South China block, and the Anderson River and other Laurussian localities presented in Table 1. Distance and water depth could well have presented obstacles, but not barriers, to slow swimmers dependent on shallow water environments.

Figure 13, based on Colpron and Nelson (2009; fig. 12), although placing the paleocontinents and terranes 15 degrees or more farther north than the $5^{\circ}-8^{\circ} \mathrm{S}$ latitude of more recent studies, presents a view of the northern margin of Laurussia in the Early Devonian (Emsian, $401 \mathrm{Ma}$ ) showing shallow marine and shelf connections between the Laurussian localities of Anderson River and Spitsbergen, (W-E) and the Siberia/New Siberian Islands terrane locality of Kotelny Island (SW-NE), as well as open water at or adjacent to the Baltic states, central Poland and Rhenish Slate localities to the southeast. 


\section{Page 29}

Open marine connections between the more northern localities and those that were near the central and southern parts of Baltica at the time it collided with Laurentia to form Laurussia, are less straightforward than they would have been in the Late Silurian and Lochkovian (Mark-Kurik et al. 2013). An Emsian connection could have been possible from the western Canadian Arctic north of and around the Old Red Sandstone Continent, through a shallow shelf separating it from Siberia (Arctic Province of Blieck and Janvier 1999). A lengthy journey through the shrinking Ural Ocean and around the northeast part of Baltica and down the Rheic Ocean coast (North Atlantic Province of Blieck and Janvier 1999) would have been required to complete the journey. While possible, this lengthy route seems unlikely. If most of the paleogeographic base maps are correct and the contact between Laurentia and Baltica was complete by the late Early Devonian, it seems probable that Heimenia, the single genus linking the Anderson River Emsian fauna with the Baltic and central Europe localities, had dispersed before the closing of open marine links. Heimenia is considered to be a marine species (MondéjarFernández and Clément 2012).

Of the genera not shared between Spitsbergen and the Anderson River, NWT, the Spitsbergen thelodont Amaltheolepis is known from the Emsian of Lithuania and the Severnaya Zemlya archipelago (Karatajuté-Talimaa 1978; Märss et al. 2007), and the Eifelian of Vestspitsbergen (Ørvig 1969; Karatajuté-Talimaa 1978), requiring a connection between Vestspitsbergen, the Baltic and Russia. Dialipina, first described from Anderson River, is known also throughout the Lower Devonian of Siberia (Gedinnian, Kotelny Island; Lochkovian and Pragian, Kotui Basin (Schultze 1977, 1992), but not from areas between Siberia and Spitsbergen. The early occurrences of Dialipina 


\section{Page 30}

indicate an Early Devonian connection from Siberia to the Canadian Arctic; the same direction from Russia to the Baltic and Spitsbergen is shown by the occurrences of Amaltheolepis. Heimenia shows an even wider distribution, including China and possibly Vietnam (Fig. 13).

\section{Discussion}

A connection between the Canadian Arctic north of and around the Old Red Sandstone continent to Spitsbergen, Siberia and the Baltic region (as in Dineley and Loeffler 1993, fig. 6.1; Blieck and Janvier 1999, fig. 9.17 [Turinia fauna connecting the Arctic and North Atlantic provinces] and Blieck and Cloutier 2000, fig. 2A) and to central Europe is necessary to explain the faunal similarities. Mark-Kurik (1991) used the communality of placoderm fishes (and partly the co-occurring fish fauna) to correlate Emsian deposits over the mentioned area. The placement of continental blocks and terranes in most recent paleogeographical reconstructions of the late Early Devonian does not accommodate such connections.

Johnson et al. (2000, fig. 10a,b), for example, using paleogeographic reconstructions by Ziegler (1988), showed that an open marine connection existed in the Silurian/earliest Early Devonian between the Baltic basin on the east of the Old Red continent south to the Rhineland, and west to western and northern North America. However, their late Early Devonian reconstruction shows the marine Baltic basin as completely enclosed. The paleogeographic reconstructions of Golonka et al. (2003, fig. 9) and Golonka and Gaweda (2012, fig. 10) reflect the facies and occurrences of the taxa discussed here (Table 1) reasonably well, but also include a closed Baltic basin. These 


\section{Page 31}

localities in Table 1 are all coastal and connected by sea in the Colpron and Nelson (2009) reconstruction (see also Blieck and Cloutier 2000, fig. 2A after McKerrow et al 1991 fig. 6). The Colpron and Nelson (2009)-based reconstruction (Fig. 13), although positioning the continental blocks and terranes farther north than most recent sources, best accommodates the evidence for paleogeographic connections provided by the occurrence of the Early/Middle Devonian fish fauna at Anderson River and the other localities in Table 1, particularly by showing an open Baltic basin and a more open "northwest passage" around the northern edge of Laurussia.

Until such time as they are found elsewhere, the mesacanthid acanthodian Melanoacanthus minutus (Cumbaa and Schultze 2002), the holoptychiid porolepiform $\mathrm{Na}$ sogaluakus chorni (Schultze 2000), and the early lungfish, Melanognathus canadensis (Jarvik 1967; Schultze 2001), are unique to the Lower Devonian (Emsian) shallow marine fauna of the Anderson River.

\section{Acknowledgments}

We dedicate this paper to the memory of the late Elga Mark-Kurik, a world authority on placoderm fishes. Elga was a paleontologist at Tallinn University of Technology, Tallinn, Estonia, Department of Paleontology and Stratigraphy. She had seen our reconstructions of the two species of Herasmius, and felt strongly that the occurrence of the same genus in Spitsbergen and Anderson River removed another endemic form and fa- 


\section{Page 32}

vored widespread marine connections among Early Devonian fish faunas.

We thank the Canadian Museum of Nature (Research Advisory Committee grants to S. L. Cumbaa) for the support of the fieldwork. We gratefully acknowledge the help of the Aurora Research Institute, Inuvik, Northwest Territories with logistical and other support, and the great help and enthusiasm of Richard Day, Canadian Museum of Nature, Ottawa, Ontario, and Dr. John Chorn, Johnston County College, Overland Park, Kansas, during the field work. Our thanks also to the Polar Continental Shelf Program, Natural Resources, Canada, for providing a grant for important logistical support to get us in and out of our field camp. Private funds were added to cover the total costs of the expedition. We thank Alan McDonald, CMN, for the preparation of the specimens, for the preparation of Figures 1 and 13 and for compositing and adjusting all the figures for publication. Thanks to the late Jörg-Peter Mendau, Berlin, who inked Figures 3B-8B and 12B, and Susan Laurie-Bourque, Ottawa, for the digital inking of Figures 2A, 2B, 9, 10A and 10B. O. Sanisidro, Lawrence, took the photos of figures 5A and 11. We thank the late Elga Mark-Kurik for suggestions and help with the Estonian literature of Heterostius. We appreciate the helpful comments by Robert Carr on an earlier version of the manuscript, and constructive comments and criticisms by our anonymous reviewers and the editor.

\section{References}

Abel, O. 1927. Ein Beitrag zur Kenntnis von Heterostius convexus Asmuss aus dem Alter Roten Sandstein von Arokülla bei Dorpat: die Gelenkverbindung zwischen dem Schädeldach und dem Rumpfpanzer. Paläontologische Zeitschrift, 9: 314-319. 


\section{Page 33}

Asmuß, H. 1856. Das vollkommenste Hautskelet der bisher bekannten Thierreihe. An fossilen Fischen des Alten Roten Sandsteins aufgefunden und aus ihren Resten erläutert. Abhandlung zur Erlangung der Magisterwürde, Universität Dorpat: 39 pp.

Birkenmajer, K. 1964. Devonian, Carboniferous and Permian Formation of Hornsund, Vestspitsbergen. Studia Geologica Polonica, 11: 47-123.

Balkwill, H. R., and Yorath, C. J. 1970. Simpson Lake Map-Area, District of Mackenzie (97B). Geological Survey of Canada, Paper 69-10: 10 pp.

Blieck, A. 1984. Les hétérostracés ptéraspidiformes, agnathes du Silurien-Dévonien du continent Nord-Atlantique et des blocs avoisants: révision systématique, phylogénie, biostratigraphie, biogéographie. Cahiers de Paléontologie, Section Vertébrés. Centre national de la Recherche scientifique - CNRS, Paris, 199 p. Blieck, A. 2009. Biodiversité, environments et évolution au Paléozoïque: le cas des Vertébrés du Cambrien au Dévonien (542 à $359 \mathrm{Ma}$ ). Annales de la Société Géologique du Nord, 16, (2. Série): 19-33.

Blieck, A., and Cloutier, R. 2000. Biostratigraphical correlations of Early Devonian vertebrate assemblages of the Old Red Sandstone Continent. Courier Forschungsinstitut Senckenberg, 223: 223-269.

Blieck, A., Goujet, D. and Janvier, P. 1987. The vertebrate stratigraphy of the Lower Devonian (Red Bay Group and Wood Bay Formation) of Spitsbergen. Modern Geology 11: 197-217.

Blieck, A., and Janvier, P. 1999. Silurian-Devonian vertebrate dominated communities, with particular reference to agnathans. In Boucot, A.J. and Lawson, J.D. (eds.) 


\section{Page 34}

Paleocommunities: A Case Study from the Silurian and Lower Devonian. P. 79105; Cambridge University Press, Cambridge, UK.

Carr, R.K. and Hlavin, W.J. 2010. Two new species of Dunkleosteus Lehman, 1956, from the Ohio Shale Formation (USA, Famennian) and the Kettle Point Formation (Canada, Upper Devonian), and a cladistic analysis of the Eubrachthoraci (Placodermi, Arthrodira). Zoological Journal of the Linnean Society, 159, 195222.

Clément, G. 2001a. Evidence for lack of choanae in the Porolepiformes. Journal of Vertebrate Paleontology, 21: 795-802.

Clément, G. 2001b. Etudes anatomiques des genres Porolepis Woodward, 1891 et Heimenia Ørvig, 1969 (“Porolepididae”, Sarcopterygii) et du genre Powichthys Jessen, 1975 (Powichthyidae, Sarcopterygii) du Dévonien Inférieur et Moyen du Spitzberg - Phylogénie des Dipnomorpha. Ph.D. dissertation, Museum national d' Histoire naturelle, Paris: 297 pp.

Colpron, M. and Nelson, J.L. 2009. A Paleozoic Northwest Passage: incursion of Caledonian, Baltican and Siberian terranes into eastern Panthalassa, and early Evolution of the North American Cordillera. In Cawood, P.A. and Kröner, A. (eds.), Earth Accretionary Systems in Space and Time. The Geological Society, London, Special Publications 318: 273-307.

Cumbaa, S. L., and Schultze, H.-P. 2002. An Early Devonian (Emsian) acanthodian from the Bear Rock Formation, Anderson River, Northwest Territories, Canada. Canadian Journal of Earth Sciences, 39: 1457-1465.

Denison, R. 1978. Placodermi. In Schultze, H.-P. (ed.) Handbook of Paleoichthyology. 


\section{Page 35}

Vol. 2: VI + 128 p. Gustav Fischer Verlag; Stuttgart, New York.

Denison R. 1984. Further consideration of the phylogeny and classification of the order Arthrodira (Pisces: Placodermi). Journal of Vertebrate Paleontology, 4(3): 396412.

Dineley, D.L. and Loeffler, E.J. 1993. Biostratigraphy of the Silurian and Devonian gnathostomes of the Euramerica province. In Long, J.A. (ed.), Palaeozoic Vertebrate Biostratigraphy and Biogeography. Chapter 6: 104-138. Belhaven Press, London.

Domeier, M. and Torsvik, T.H. 2014. Plate tectonics in the late Paleozoic. Geoscience Frontiers 5: 303-350.

Dupret, V., Zhu M. and Wang J.-Q. 2009. The morphology of Yujiangolepis liujingensis (Placodermi, Arthrodira) from the Pragian of Guangxi (south China) and its phylogenetic significance. Zool. J. Linn. Soc. 2009: 1-13.

Elliott, D. K. and Carr, R. K. 2010. A new species of Bryantolepis Camp, Welles, and Green, 1949 (Placodermi, Arthrodira) from the Early Devonian Water Canyon Formation of northern Utah and southern Idaho, with comments on the endocranium. Kirtlandia 57:22-35.

Giles, S., Friedman, M. and Brazeau, M.D. 2015. Osteichthyan-like cranial conditions in An Early Devonian stem gnathostome. Nature 520 (7545): 82-85. doi: $10.1038 /$ nature14065

Golonka, J., Bocharova, N.Y., Ford, D., Edrich, M.E., Bednarczyk, J. and Wildharber, J. 2003. Paleogeographic reconstructions and basins development of the Arctic. In Golonka, J. (ed.), Thematic set on paleogeographic reconstruction and 


\section{Page 36}

Hydrocarbon basins: Atlantic, Caribbean, South America, Middle East, Russian Far East, Arctic. Marine and Petroleum Geology 20(2003) 211-248.

Golonka, J. and Gaweda, A. 2012. Plate tectonic evolution of the southern margin of Laurussia in the Paleozoic. In Sharkov, E.V. (ed.) Tectonics - Recent Advances. Chapter 10: 261-282.

Goujet, D. 1984. Les poissons placoderms du Spitsberg: arthrodires dolichothoraci de la Formation de Wood Bay (Dévonien Infèrieur). Cahiers de Paléontologie, Section Vértébres, Editions du Centre national de la Recherche scientifique - CNRS, Paris. $254 \mathrm{p}$.

Goujet, D. and Emig, C.C. 1985. Des Lingula fossils, indicateurs de modifications de 1' Environnement dans un gisement du Dévonien inférieur du Spitsberg. C.R. Acad. Sc. Paris, t. 301, Série II, nº 13, 945-948.

Gross W. 1932. Die Arthrodira Wildungens. Geologische und Palaeontologische Abhand lungen, 19: 5-61.

Gross, W. 1933. Die Wirbeltiere des rheinischen Devons. Abhandlungen der Preußischen Geologischen Landesanstalt, (Neue Folge), 154: 1-83.

Heintz, A. 1930. Eine neue Rekonstruktion von Heterostius Asm. Sitzungsberichte der Naturforschenden Gesellschaft Dorpat, 36: 167-173.

Heintz, A. 1932. The structure of Dinichthys. A contribution to our knowledge of the Arthrodira. In Gudger, E. W. The Bashford Dean Memorial Volume Archaic Fish es. Art. 4: 115-224. American Museum of Natural History, New York. 


\section{Page 37}

Heintz, A. 1934. Revision of the Estonian Arthrodira. Part 1. Family Homosteidae Jaekel. Eesti Loodusteaduse Arhiiv, 1 Serie: Geologica, Chemica et Physica, 10: 177291. (= Archiv für die Naturkunde Estlands)

Jaekel, O. 1903. Die Organisation und systematische Stellung der Asterolepiden. Zeitschrift der deutschen geologischen Gesellschaft, 55: 41-60.

Jarvik, E. 1967. On the structure of the lower jaw in dipnoans: with a description of an early dipnoan from Canada, Melanognathus canadensis gen. et sp. nov. In Fossil Vertebrates. Edited by C. Patterson, and P. H. Greenwood. Journal of the Linnean Society, Zoology 47: 155-183.

Jessen, H. L. 1989. Ein rhipidistier Fischrest aus den Kerf-Schichten (oberes UnterDevon) der Eifel (Rheinisches Schiefergebirge). Palaeontographica A, 206: 1724.

Johnson, H.G., Elliott, D.K. and Wittke, J.H. 2000. A new actinolepid arthrodire (Class Placodermi) from the Lower Devonian Sevy Dolomite, East-Central Nevada. Zoological Journal of the Linnean Society 129: 241-266.

Karatajuté-Talimaa, V. 1978. [Silurian and Devonian thelodonts of the USSR and Spits bergen]. 344p. Mokslas, Vilnius. [in Russian].

Kent, D.V. and Van der Loo, R. 1990. Palaeozoic palaeogeography from Palaeomagnetism of the Atlantic-bordering continents. Geological Society, London, Memoirs 12: 49-56. doi: 10.1144/GSL.MEM.1990.012.01.04

Kuršs, V. 1992. Depositional environment and burial conditions of fish remains in the Baltic Middle Devonian. Academia 1: 251-260.

Lawver, L.A., Gahagan, L.M., and Norton, I. 2011. Palaeogeographic and tectonic evo 


\section{Page 38}

lution of the Arctic region during the Paleozoic. In Spencer, A.M., Embry, A.F., Gautier, D.L., Stoupakova, A.V. and Sorenson, K. (eds), Arctic Petroleum Geology. Geological Society, London, Memoirs 35 (Chapter 5): 61-77. http://dx.doi.org/10.1144/M35.5.

Lukševičs, E., Lebedev, O.A., Zakharenko, G.V., 2010. Palaeozoogeographical connections of the Devonian vertebrate communities of the Baltica Province. Part I.

Early-Middle Devonian. Palaeoworld 19 (1-2), 108-128.

Lyarskaya, L. A. 1981. [Baltic Devonian Placodermi - Asterolepididae]. Zinatne, Riga: 152 pp. [Russian with Engl. abstr.]

Mark-Kurik, E. 1974. Discovery of new Devonian fish localities in the Soviet arctic.

Eesti NSV Teaduste Akadeemia Toimetised (Keemia, Geoloogia), 23: 332-335.

Mark-Kurik, E. 1991a. Contribution to the correlation of the Emsian (Lower Devonian) on the basis of placoderm fishes. Newsletters on Stratigraphy 25 (1): 11-23.

Mark-Kurik, E. 1991b. On the environment of Devonian fishes. Eesti Teaduste

Akadeemia Toimetised, Geoloogia 40: 122-135.

Mark-Kurik, E., Blieck, A., Burrow, C.J. and Turner, S. 2013. Early Devonian fishes From coastal De Long Strait, central Chukota, Arctic Russia. Geodiversitas 35(3): 545-578.

Märss, T., Turner, S., and Karatajūté-Talimaa, V. 2007. "Agnatha II" Thelodonti. In Handbook of Paleoichthyology. Edited by H.-P. Schultze, vol. 1B: 143 pp. Verlag Dr. F. Pfeil, München. 
Page 39

M'Coy, F. 1848. On some new fossil fish of the Carboniferous period. Annals and Magazine of natural History, (2) 2:1-10. 115-133.

McKerrow, W.S., Dewey, J.F. and Scotese, C.R. 1991. The Ordovician and Silurian development of the Iapetus ocean. In Bassett, M.G., Land, P.D. and Edwards, D. (eds.) The Murchison Symposium (Proceedings, International Conference Silurian System, Keele, 1989). Paleontology, Special Paper 44: 165-178.

Mondéjar-Fernández, J., and Clément, G. 2012. Squamation and scale microstructure evolution in the Porolepiformes (Sarcopterygii, Dipnomorpha) based on Heimenia ensis from the Devonian of Spitsbergen. Journal of Vertebrate Paleontology, 32(2): 267-284.

Norris, A.W. 1997. Devonian. In Norris, D.K. (ed.), The geology, mineral and hydrocarbon potential of northern Yukon Territory and northwestern District of Mackenzie. Geological Survey of Canada, Bulletin 422: 163-200.

Ørvig, T. 1969. Vertebrates from the Wood Bay Group and the position of the EmsianEifelian boundary in the Devonian of Vestspitsbergen. Lethaia 2: 273-328.

Pernègre, V.N. and Blieck, A. 2016. A revised heterostracan-based ichthyostratigraphy of the Wood Bay Formation (Lower Devonian, Spitsbergen), and correlation with Russian Arctic archipelagos. Geodiversitas 38(1): 5-20. http://dx.doi.org/10.5252/g2016n1a1

Piepjohn, K. 1997. Erläuterungen zur Geologischen Karte 1:150.000 des WoodfjordenGebietes (Haakon VII Land, Andrée Land), NW-Spitzbergen, Svalbard. Münstersche Forschungen zur Geologie und Paläontologie, 82: 15- 37 with 1 geol. map. 
Page 40

Schultze, H.-P. 1968. Palaeoniscoidea-Schuppen aus dem Unterdevon Australiens und Kanadas und aus dem Mitteldevon Spitzbergens. Bulletin of the British Museum (Natural History), Geology, 16: 341-368.

Schultze, H.-P. 1977. Ausgangsform and Entwicklung der rhombischen Schuppen der Osteichthyes (Pisces). Paläontologische Zeitschrift, 51: 152-168.

Schultze, H.-P. 1992. Early Devonian actinopterygians (Osteichthyes, Pisces) from Siberia. In Fossil fishes as living animals. Edited by E. Mark-Kurik. Academia 1: 233-242. Tallinn, Estonia.

Schultze, H.-P. 2000. A porolepiform rhipidistian from the Lower Devonian of the Canadian Arctic. Mitteilungen aus dem Museum für Naturkunde in Berlin, Geowissenschaftliche Reihe, 3: 97-107.

Schultze, H.-P. 2001. Melanognathus, a primitive dipnoan from the Lower Devonian of the Canadian Arctic and the interrelationships of Devonian dipnoans. Journal of Vertebrate Paleontology, 21: 781-794.

Schultze, H.-P., and Cumbaa, S. L. 2001. Dialipina and the characters of basal actinopterygians. In Major events in early vertebrate evolution. palaeontology, phylogeny and development. Edited by P.E. Ahlberg. Systematic Association, Special Vol., Series 61. Taylor and Francis, London, pp. 315-332.

Scotese, C.R. 1986. Phanerozoic reconstructions: a new look at the assembly of Asia. University of Texas Institute for Geophysics, Technical Report 66: 1-54. Scotese, C.R. and McKerrow, W.S. 1990. Revised world maps and introduction. In: McKerrow, W.S. and Scotese, C.R. (eds.) Palaeozoic palaeogeography and bioGeography (Symposium Oxford, 1988). Geological Society, London, Memoirs 


\section{Page 41}

12: $1-21$.

Thanh, T. D., and Janvier, P. 1987. Les vertebras dévoniens du Vietnam. Annales des Paléontologie (Vert.-Invert.), 73: 165-194.

Torsvik, T.H. and Cocks, L.R.M. 2013. Gondwana from top to base in space and time. Gondwana Research 24(3-4): 999-1030.

Wang J.-Q. 1986. [The discovery of Heimenia in China]. PalAsiatica, 24: 75-77. [Chinese with Engl. abstr.]

Wang J.-Q. and Wang N-Z. 1984. New material of arthrodira from the Wuding region, Yunnan. Vertebrata PalAsiatica, 22: 1-7. [Chinese with Engl. summary] Wehrmann, A., Hertweck, G., Brocke, R., Jansen, U., Königshof, P., Plodowski, G., Schindler, E., Wilde, V., Blieck, A. and Schultka, S. 2005. Paleoenvironment of an Early Devonian land-sea transition: a case study from the southern margin of the Old Red Continent (Mosel Valley, Germany). Palaios 20: 101-120.

Witzke, B.J. 1990. Palaeoclimatic constraints for Palaeozoic palaeolatitudes of Laurentia and Euramerica. In McKerrow, W.S. and Scotese, C.R. (eds.) Palaeozoic palaeogeography and biogeography (Symposium Oxford, 1988). Geological Society, London, Memoirs 12: 243-255.

Woodward, A. S. 1891. Catalogue of the fossil fishes in the British Museum. Part II. Containing the Elasmobranchii (Acanthodii), Holocephali, ichthyodorulites, Ostracodermi, Dipnoi, and Teleostomi (Crossopterygii), and chondrostean Actinopterygii. XLIV + 567pp; Taylor and Francis, London.

Young, G. 1981. New Early Devonian brachythoracids (placoderm fishes) from the Tamas-Wee Jasper region of New South Wales. Alcheringa, 5: 245-271. 


\section{Page 42}

Young, G. 1990. Devonian vertebrate distribution patterns and cladistic analysis of Palaeogeographic hypotheses. In McKerrow, W.S. and Scotese, C.R. (eds.) Palaeozoic palaeogeography and biogeography (Symposium Oxford, 1988).

Geological Society, London, Memoirs 12: 243-255.

Zhao, W.-J. and Zhu, M. 2010. Siluro-Devonian vertebrate biostratigraphy and biogeography of China. Palaeoworld 19: 4-26.

Zhu Y-A. and Zhu M. 2013. A redescription of Kiangyousteus yohii (Arthrodira:

Eubrachythoraci) from the Middle Devonian of China, with remarks on the systematics of the Eubrachythoraci. Zoological Journal of the Linnean Society, 169: 798819.

Zhu Y-A., Zhu M. and Wang J-Q. 2016. Redescription of Yinostius major (Arthrodira: Heterostiidae) from the Lower Devonian of China, and the interrelationships of Brachythoraci. Zoological Journal of the Linnean Society, 176: 806-834.

Ziegler, P.A. 1981. Evolution of sedimentary basins in north-west Europe. In Illing, L.V. and Hobson, G.P. (eds.) Petroleum Geology of the Continental Shelf of NorthWest Europe. P1 3-39. Heyden, London.

Ziegler, P.A. 1988. Evolution of the Arctic-North Atlantic and the Western Tethys. American Association of Petroleum Geologists, Memoir 43. 200 p. 


\section{Page 43}

Table 1. Lower Devonian localities, shared genera, and paleogeographic units.

Lower Devonian

Locality

Anderson River, NWT, Canada

(this paper; Schultze

2000; Schultze 1968;

Schultze \& Cumbaa

2001)

Vestspitsbergen,

Svalbard, Norway

(Ørvig 1969; Clément

2001b; Mondéjar-

Fernández \& Clément

2012)

Lithuania, Poland, Belarus

(Lyarskaya 1981; Clément

2001a; Ørvig 1969)

Rhenish Slate Massif,

Germany

(Jessen 1989)

Kotelny Island, Siberia, Actinopterygii

Russia

(Schultze 1977, 1992)

Yunnan and Sichuan,

China; ?NE Vietnam

(Zhao \& Zhu 2010; Wang

1986; Zhu 2000; Tranh \&

Janvier 1987)

Porolepiformes

- Heimenia

Porolepiformes

- Heimenia

- Dialipina

Actinopterygii

- Dialipina

Porolepiformes

- Heimenia
Paleocontinent or Terrane

Shared Genera Mid-Late Silurian Early Devonian

Arthrodira

Laurentia

Laurussia

- Herasmius

Actinopterygii

- Dialipina

Porolepiformes

- Heimenia

Arthrodira

- Herasmius

Porolepiformes

- Heimenia

Laurussia

Baltica

Laurussia

Baltica

Laurussia

New Siberian

Siberia +

Islands terrane

New Siberian

Islands

South China

South China 


\section{Page 44}

Figure captions

Figure 1.

Localities along Anderson River: AND-3 and -3A, and AND-4 and -4A are localities on the opposite sides of the river; these localities belong to same horizon. AND-5 lies about $7 \mathrm{~km}$ down the river from locality AND-3. Db, Lower Devonian; Ks, Upper Cretaceous. Geological mapping based on Balkwill and Yorath (1970).

\section{Figure 2.}

Herasmius granulatus Ørvig, 1969. A. Reconstruction of skull roof of holotype by Ørvig (1969, fig. 3A); B. Reconstruction of skull roof of holotype based on nuchal and central plates of $H$. dayi without tectonic distortion. Verdalen Member, Stjørdalen Formation, Wood Bay Group, Emsian/Eifelian; Vestspitsbergen. Ce, central plate; Nu, nuchal plate.

\section{Figure 3.}

Herasmius dayi n. sp., holotype CMN FV 54694, posterior skull roof + anterior shoulder girdle in dorsal view; Bear Rock Formation, upper Emsian; Anderson River, N.W.T., Canada. A. photograph; B. interpretative drawing. Adl, anterior dorso-lateral plate; Al, antero-lateral plate; Ce, central plate; ioc.ot, otic branch of the infraorbital line; lc, main lateral line; $\mathrm{Mg}$, marginal plate; $\mathrm{Md}$, median dorsal plate; $\mathrm{Nu}$, nuchal plate; $\mathrm{Pnu}$, paranuchal plate; Pdl, posterior dorso-lateral plate; pmc, postmarginal sensory line; Pmg, postmarginal plate; ppl, posterior pit line; Sm, submarginal plate. Scale bar $=1 \mathrm{~cm}$. 


\section{Page 45}

Figure 4.

Herasmius dayi n. sp., CMN FV 54699, median dorsal, right anterior dorso-lateral with antero-lateral, and left central plates; Bear Rock Formation, upper Emsian; Anderson River, N.W.T., Canada. A. photograph; B. drawing; C. specimen in the field. Adl, anterior dorso-lateral plate; Al, antero-lateral plate; cc, central lateral line; $\mathrm{Ce}$, central plate; Md, median dorsal plate; o.Md, area of Adl overlapped by Md; ppl, posterior pit line; soc, supraorbital lateral line. Scale bar in drawing $=1 \mathrm{~cm}$.

\section{Figure 5 .}

Herasmius dayi n. sp., CMN FV 54700a, left submarginal plate in lateral view; Bear Rock Formation, upper Emsian; Anderson River, N.W.T., Canada. A. photograph; B. drawing. Scale bar in drawing $=1 \mathrm{~cm}$. Dialipina scale visible above center of submarginal.

Figure 6.

Herasmius dayi n. sp., CMN FV 54665 left suborbital plate from the inside; Bear Rock Formation, upper Emsian; Anderson River, N.W.T., Canada. A. photograph; B. drawing. Scale bar $=1 \mathrm{~cm}$.

\section{Figure 7.}

Herasmius dayi n. sp., CMN FV 54697, left suborbital from the inside, infragnathal from the inside, and unidentified bone. A. photograph; B. drawing. ioc.pt, postorbital part of 


\section{Page 46}

infraorbital sensory line; Ig, ?infragnathal; Pto, postorbital plate; So, suborbital plate. Scale in drawing $=1 \mathrm{~cm}$.

\section{Figure 8.}

Herasmius dayi n. sp., CMN FV 54700b, left anterior dorso-lateral (antero-lateral broken off) and posterior dorso-lateral plates in lateral view; Bear Rock Formation, upper Emsian; Anderson River, N.W.T., Canada. A. photograph; B. drawing. Adl, anterior dorso-lateral plate; gp, glenoid process; lc, main lateral line; o.Md, area of Adl overlapped by median dorsal plate; o. Pl, area of Adl overlapped by median dorsal plate; Pdl, posterior dorso-lateral plate; sgp, subglenoid process. Scale bar in drawing $=1 \mathrm{~cm}$.

Figure 9.

Herasmius dayi n. sp., reconstruction of skull roof and shoulder girdle in dorsal view based on holotype CMN FV 54694, 54699 (central, antero-lateral and median dorsal plates), 54665 (suborbital plate) and 54700a (submarginal plate); Adl, anterior dorsolateral plate; Al, antero-lateral plate; cc, central lateral line; Ce, central plate; ioc.ot, otic portion of the infraorbital sensory line; lc, main lateral line; $\mathrm{Md}$, median dorsal plate; $\mathrm{Mg}$, marginal plate; $\mathrm{Nu}$, nuchal plate; Pdl, posterior dorso-lateral plate; Pmg, postmarginal plate; Pi, pineal plate; Pl, postero-lateral plate; pmc, postmarginal sensory line; Pn; paranuchal plate; Pro, preorbital plate; Pto, postorbital plate; Ro, rostral plate; Sm, submarginal plate; So, suborbital plate; soc, Supraorbital sensory line. Bear Rock Formation, upper Emsian; Anderson River, N.W.T., Canada. 


\section{Page 47}

Figure 10.

A. Heterostius ingens Asmuß, 1856, reconstruction of skull and shoulder girdle in dorsal view after Heintz (1930, fig. 2). Aruküla beds, Eifelian, Middle Devonian; Estonia. B. Yinostius major Wang and Wang, 1984; reconstruction of skull and shoulder girdle in dorsal view after Wang and Wang (1984, fig. 2). Jiucheng Formation, upper Emsian, Lower Devonian; near Wuding, Yunnan Province, south-western China.

Adl, anterior dorso-lateral plate; Al, antero-lateral plate; cc, central lateral line; Ce, central plate; ioc, infraorbital sensory line; ioc.ot, otic portion of the infraorbital sensory line; lc, main lateral line; $\mathrm{Md}$, median dorsal plate; $\mathrm{Mg}$, marginal plate; $\mathrm{Nu}$, nuchal plate; orb, orbit; Pdl, posterior dorso-lateral plate; Pmg, postmarginal plate; Pi, pineal plate; Pl, postero-lateral plate; pmc, postmarginal sensory line; Pn; paranuchal plate; Pro, preorbital plate; Pto, postorbital plate; Ro, rostral plate; Sm, submarginal plate; So, suborbital plate; soc, supraorbital sensory line.

Figure 11 .

'Bryantolepis;' unidentified plate, CMN FV 54691B; Bear Rock Formation, upper Emsian; Anderson River, N.W.T., Canada. Scale bar $=1 \mathrm{~cm}$.

Figure 12.

'Dunkleosteus'; suborbital plate, CMN FV 54827, in lateral view. ioc.so, suborbital portion of infraorbital sensory canal. A. photograph; B. drawing; scale in drawing $=1 \mathrm{~cm}$. Bear Rock Formation, upper Emsian; Anderson River, N.W.T., Canada. 


\section{Page 48}

Figure 13.

Early Devonian (late Emsian, c. $395 \mathrm{Ma}$ ) paleogeographic reconstruction, based on Colpron and Nelson (2009, fig. 12). Localities shown as in Table 1: 1- Anderson River, NWT, Canada; 2 - Vestspitsbergen, Svalbard, Norway; 3- Baltic (Lithuania, Poland, Belarus); 4 - Rhenish Slate Massif, Germany; 5 - Kotelny Island, Siberia, Russia; 6 Beichuan, Sichuan, China and Ludian, Yunnan, China. The possible Heimenia occurrence in northeastern Vietnam is included here with the localities from China. $\mathrm{AFR}=$ Africa, $\mathrm{ARB}=\mathrm{Arabia}, \mathrm{AVL}=$ Avalonia, $\mathrm{BAL}=$ Baltica, $\mathrm{IND}=\mathrm{India}$, $\mathrm{KAZ}=$ Kazakhstania, LAU $=$ Laurentia, MEX=Mexico, $\mathrm{SCH}=$ South China, $\mathrm{SEU}=$ Southern Europe, $\mathrm{SIB}=$ Siberia. Shaded areas indicate orogenies, including the Appalachians and Caledonides along the medial margins of Laurentia and Baltica. Dashed outline represents possible crustal fragment now submerged in the Arctic Ocean. More recent paleogeographic reconstructions (e.g., Golonka and Gaweda 2012; Domeier and Torsvik 2014) shift the plates farther south, by roughly $15-18^{\circ}$. This suggests a paleolatitude of $5^{\circ}-8^{\circ} \mathrm{S}$ for Locality 1. 
Table 1. Lower Devonian localities, shared genera, and paleogeographic units.

Lower Devonian

Locality

Anderson River,

NWT, Canada

(this paper; Schultze

2000; Schultze 1968;

Schultze \& Cumbaa

2001)

Vestspitsbergen,

Svalbard, Norway

(Ørvig 1969; Clément

2001b; Mondéjar-

Fernández \& Clément

2012)

Lithuania, Poland, Belarus

(Lyarskaya 1981; Clément

2001a; Ørvig 1969)

Rhenish Slate Massif,

Germany

(Jessen 1989)

Kotelny Island, Siberia, Actinopterygii

Russia

(Schultze 1977, 1992)

Yunnan and Sichuan,

China; ?NE Vietnam

(Zhao \& Zhu 2010; Wang

1986; Zhu 2000; Tranh \&

Janvier 1987)

Arthrodira

- Herasmius

Actinopterygii

- Heimenia

Arthrodira

- Herasmius

Porolepiformes

- Heimenia

Porolepiformes

- Heimenia

Porolepiformes

- Heimenia

- Dialipina

Actinopterygii

- Dialipina

Porolepiformes

- Heimenia
Paleocontinent or Terrane

Shared Genera Mid-Late Silurian Early Devonian

Laurentia

Laurussia

- Dialipina

Porolepiformes

Svalbard

Laurussia

Baltica

Laurussia

Baltica

Laurussia

New Siberian

Siberia +

Islands terrane

New Siberian

Islands

South China

South China 


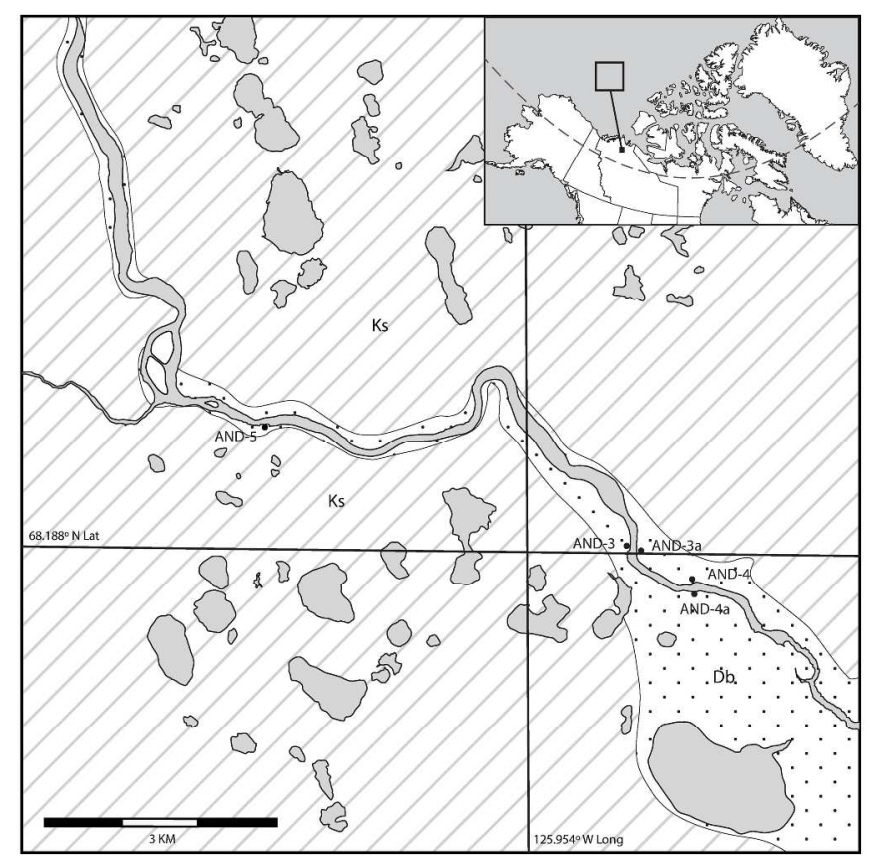

Figure 1.

Localities along Anderson River: AND-3 and -3A, and AND-4 and -4A are localities on the opposite sides of the river; these localities belong to same horizon. AND-5 lies about $7 \mathrm{~km}$ down the river from locality AND3. Db, Lower Devonian; Ks, Upper Cretaceous. Geological mapping based on Balkwill and Yorath (1970).

Introduction, after Line 74

$279 \times 364 \mathrm{~mm}(300 \times 300 \mathrm{DPI})$ 

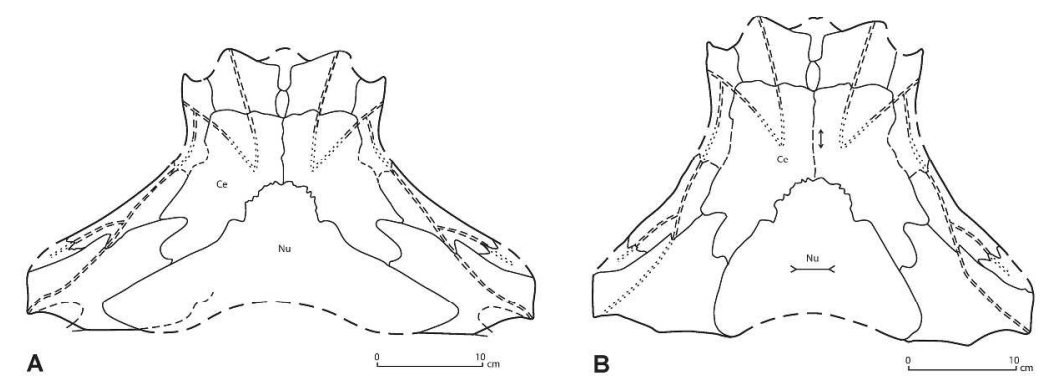

Figure 2.

Herasmius granulatus Ørvig, 1969. A. Reconstruction of skull roof of holotype by Ørvig (1969, fig. 3A); B. Reconstruction of skull roof of holotype based on nuchal and central plates of $\mathrm{H}$. dayi without tectonic distortion. Verdalen Member, Stjørdalen Formation, Wood Bay Group, Emsian/Eifelian; Vestspitsbergen. Ce, central plate; Nu, nuchal plate.

after line 195, page 9

$279 \times 361 \mathrm{~mm}(300 \times 300 \mathrm{DPI})$ 

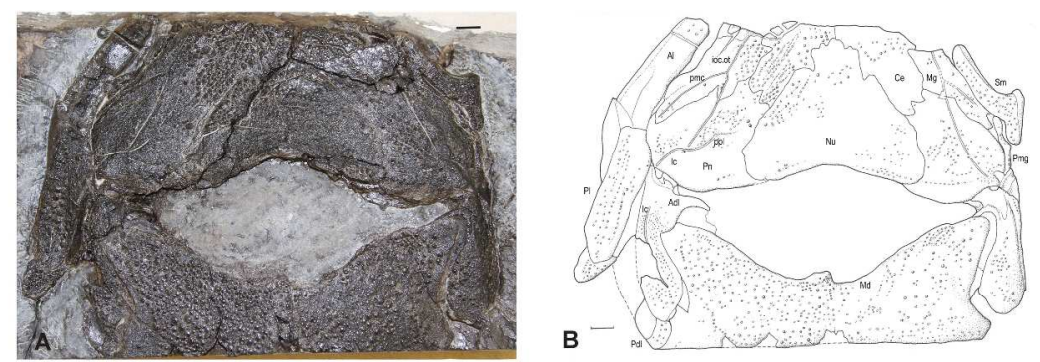

Figure 3.

Herasmius dayi n. sp., holotype CMN FV 54694, posterior skull roof + anterior shoulder girdle in dorsal view; Bear Rock Formation, upper Emsian; Anderson River, N.W.T., Canada. A. photograph; B. interpretative drawing. Adl, anterior dorso-lateral plate; Al, antero-lateral plate; Ce, central plate; ioc.ot, otic branch of the infraorbital line; Ic, main lateral line; Mg, marginal plate; Md, median dorsal plate; Nu, nuchal plate; Pnu, para-nuchal plate; Pdl, posterior dorso-lateral plate; pmc, postmarginal sensory line; Pmg, postmarginal plate; ppl, posterior pit line; Sm, submarginal plate. Scale bar $=1 \mathrm{~cm}$.

after line 228, page 10

$279 \times 361 \mathrm{~mm}(300 \times 300$ DPI $)$ 

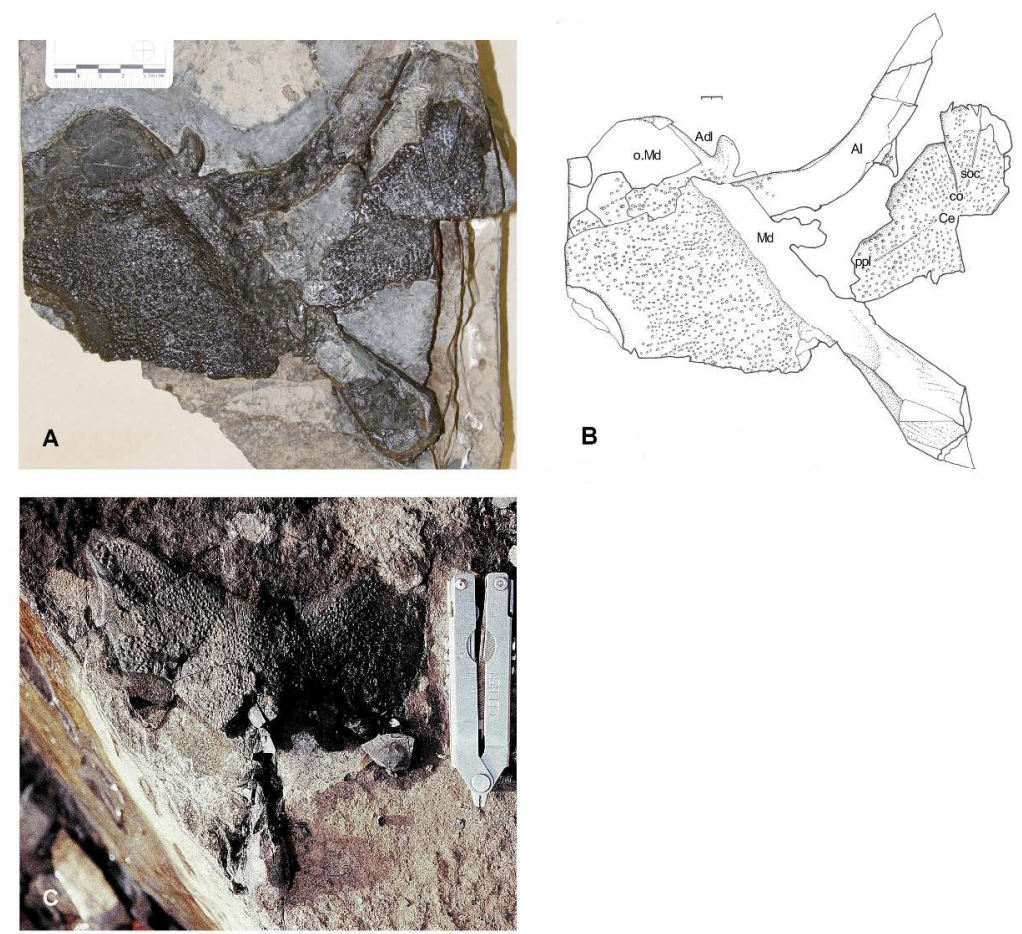

Figure 4.

Herasmius dayi n. sp., CMN FV 54699, median dorsal, right anterior dorso-lateral with antero-lateral, and left central plates; Bear Rock Formation, upper Emsian; Anderson River, N.W.T., Canada. A. photograph; B. drawing; C. specimen in the field. Adl, anterior dorso-lateral plate; Al, antero-lateral plate; $c c$, central lateral line; Ce, central plate; Md, median dorsal plate; o.Md, area of Adl overlapped by Md; ppl, posterior pit line; soc, supraorbital lateral line. Scale bar in drawing $=1 \mathrm{~cm}$.

after line 296, page 13

$279 \times 361 \mathrm{~mm}(300 \times 300 \mathrm{DPI})$ 


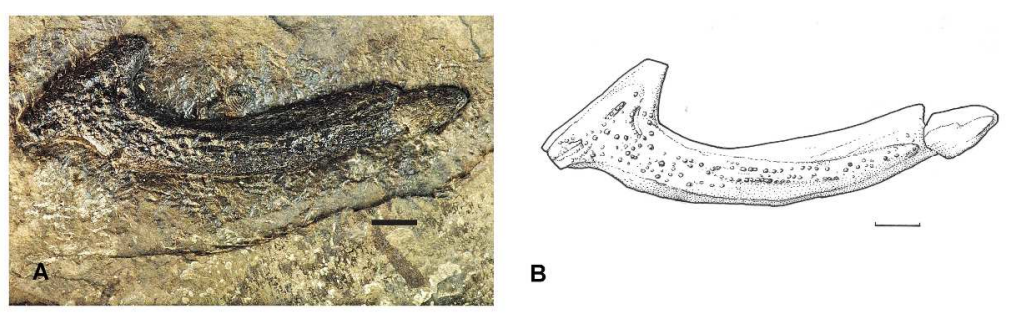

Figure 5.

Herasmius dayi n. sp., CMN FV 54700a, left submarginal plate in lateral view; Bear Rock Formation, upper Emsian; Anderson River, N.W.T., Canada. A. photograph; B. drawing. Scale bar in drawing = 1cm. Dialipina scale visible above center of submarginal.

after line 305 , page 14

$279 \times 361 \mathrm{~mm}(300 \times 300 \mathrm{DPI})$ 

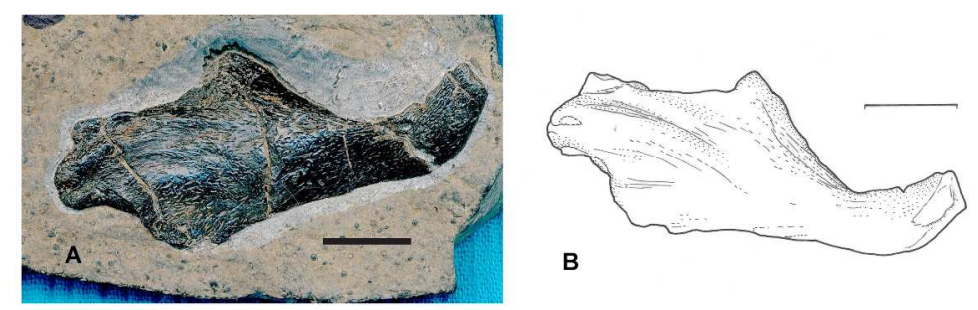

Figure 6.

Herasmius dayi n. sp., CMN FV 54665 left suborbital plate from the inside; Bear Rock Formation, upper Emsian; Anderson River, N.W.T., Canada. A. photograph; B. drawing. Scale bar $=1 \mathrm{~cm}$.

after line 314, Page 14

$279 \times 361 \mathrm{~mm}(300 \times 300 \mathrm{DPI})$ 

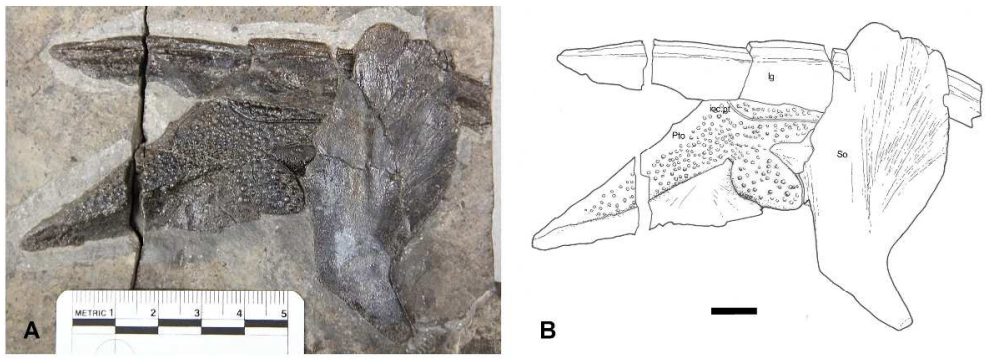

Figure 7.

Herasmius dayi n. sp., CMN FV 54697, left suborbital from the inside, infragnathal from the inside, and unidentified bone. A. photograph; B. drawing. ioc.pt, postorbital part of infraorbital sensory line; Ig, ?infragnathal; Pto, postorbital plate; So, suborbital plate. Scale in drawing $=1 \mathrm{~cm}$.

page 14 , after line 314

$279 \times 361 \mathrm{~mm}(300 \times 300 \mathrm{DPI})$ 

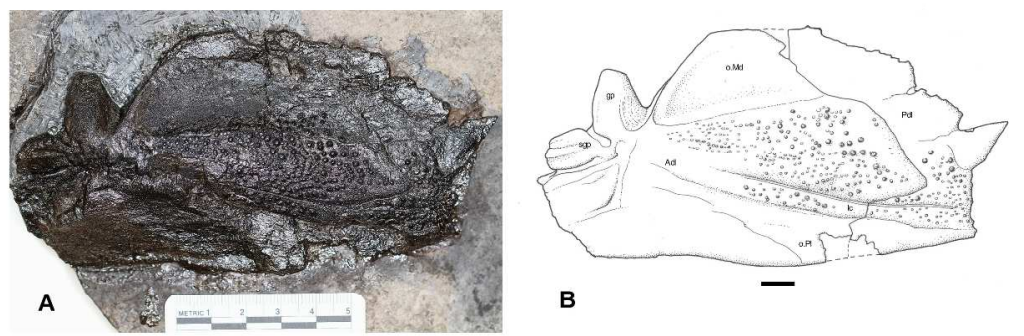

Figure 8.

Herasmius dayi n. sp., CMN FV 54700b, left anterior dorso-lateral (antero-lateral broken off) and posterior dorso-lateral plates in lateral view; Bear Rock Formation, upper Emsian; Anderson River, N.W.T., Canada. A. photograph; B. drawing. Adl, anterior dorso-lateral plate; gp, glenoid process; Ic, main lateral line; o.Md, area of Adl over-lapped by median dorsal plate; o. Pl, area of Adl overlapped by median dorsal plate; Pdl, posterior dorso-lateral plate; sgp, subglenoid process. Scale bar in drawing $=1 \mathrm{~cm}$.

page 16 , after line 346

$279 \times 361 \mathrm{~mm}(300 \times 300 \mathrm{DPI})$ 


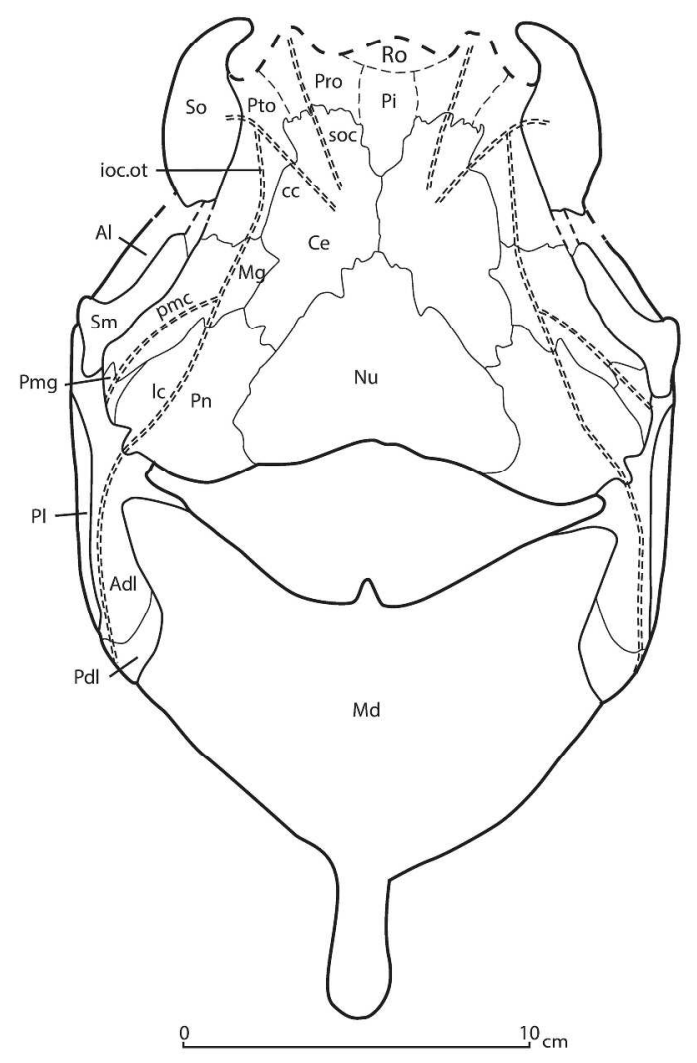

Figure 9.

Herasmius dayi n. sp., reconstruction of skull roof and shoulder girdle in dorsal view based on holotype CMN FV 54694, 54699 (central, antero-lateral and median dorsal plates), 54665 (suborbital plate) and 54700a (submarginal plate); Adl, anterior dorso-lateral plate; Al, antero-lateral plate; cc, central lateral line; Ce, central plate; ioc.ot, otic portion of the infraorbital sensory line; Ic, main lateral line; Md, median dorsal plate; Mg, marginal plate; Nu, nuchal plate; Pdl, posterior dorso-lateral plate; Pmg, postmarginal plate; Pi, pineal plate; PI, postero-lateral plate; pmc, postmarginal sensory line; Pn; paranuchal plate; Pro, preorbital plate; Pto, postorbital plate; Ro, rostral plate; Sm, submarginal plate; So, suborbital plate; soc, Supraorbital sensory line. Bear Rock Formation, upper Emsian; Anderson River, N.W.T., Canada.

page 18 , after line 394

$282 \times 369 \mathrm{~mm}(300 \times 300 \mathrm{DPI})$ 


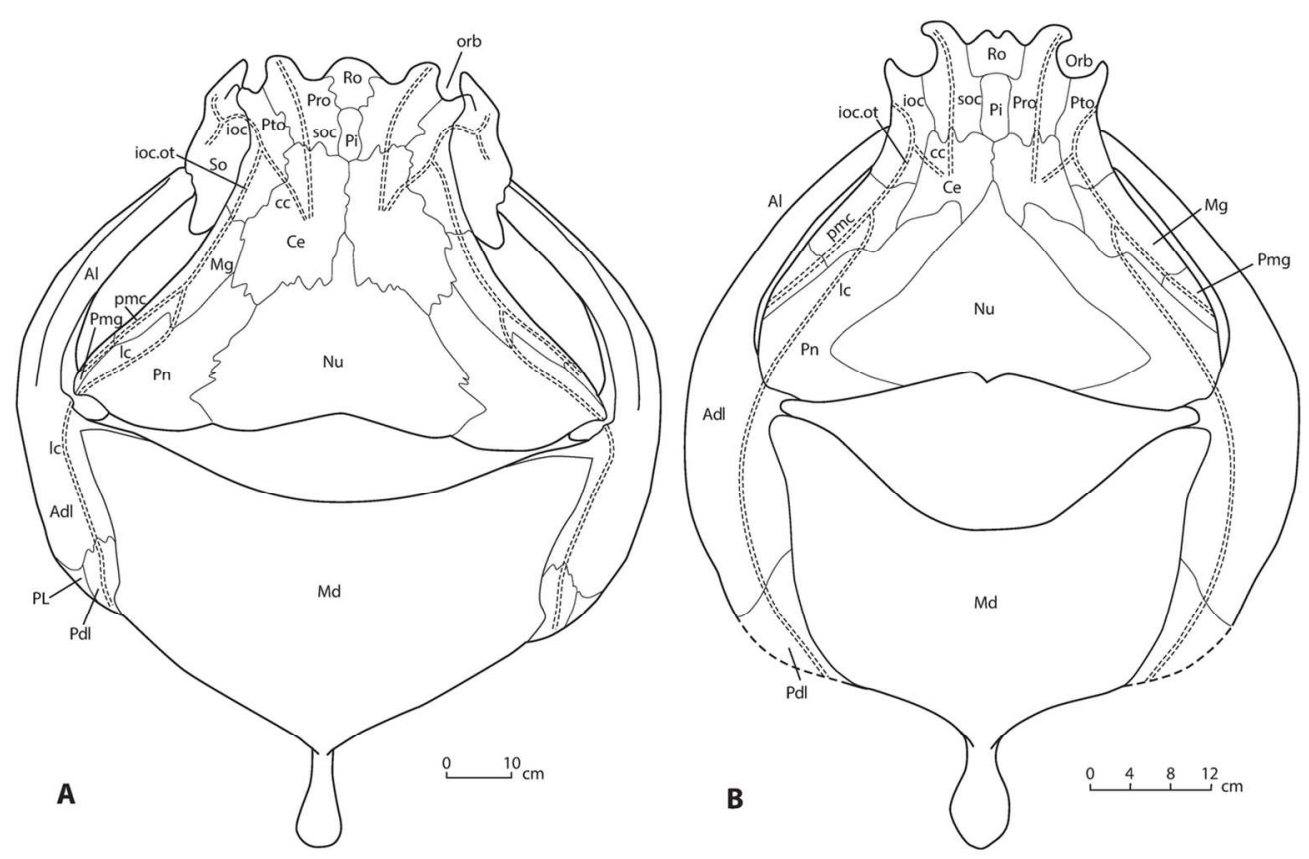

Figure 10.

A. Heterostius ingens Asmuß, 1856, reconstruction of skull and shoulder girdle in dorsal view after Heintz (1930, fig. 2). Aruküla beds, Eifelian, Middle Devonian; Estonia. B. Yinostius major Wang and Wang, 1984; reconstruction of skull and shoulder girdle in dorsal view after Wang and Wang (1984, fig. 2). Jiucheng

Formation, upper Emsian, Lower Devonian; near Wuding, Yunnan Province, south-western China. Adl, anterior dorso-lateral plate; $\mathrm{Al}$, antero-lateral plate; $\mathrm{Cc}$, central lateral line; $\mathrm{Ce}$, central plate; ioc, infraorbital sensory line; ioc.ot, otic portion of the infraorbital senso-ry line; Ic, main lateral line; Md, median dorsal plate; Mg, marginal plate; Nu, nuchal plate; orb, orbit; Pdl, posterior dorso-lateral plate; Pmg, postmarginal plate; $\mathrm{Pi}$, pineal plate; $\mathrm{Pl}$, postero-lateral plate; pmc, postmarginal sensory line; $\mathrm{Pn}$; paranuchal plate; Pro, preorbital plate; Pto, postorbital plate; Ro, rostral plate; Sm, submarginal plate; So, suborbital plate; soc, supraorbital sensory line.

$119 \times 77 \mathrm{~mm}(300 \times 300 \mathrm{DPI})$ 


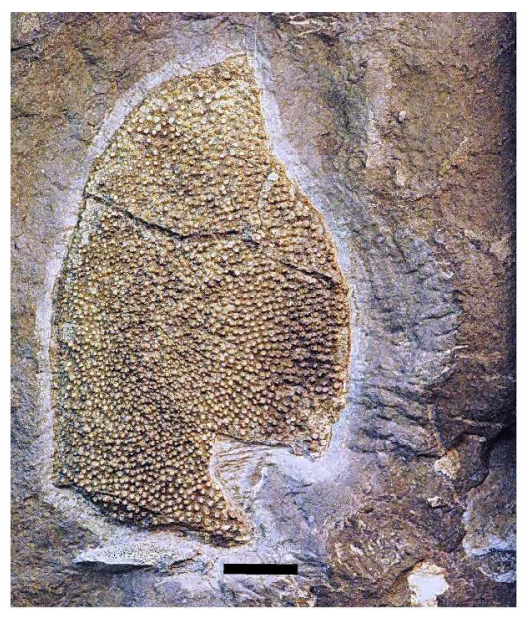

Figure 11.

'Bryantolepis;' unidentified plate, CMN FV 54691B; Bear Rock Formation, upper Emsian; Anderson River, N.W.T., Canada. Scale bar $=1 \mathrm{~cm}$.

page 21 , after line 479

$279 \times 361 \mathrm{~mm}(300 \times 300 \mathrm{DPI})$ 

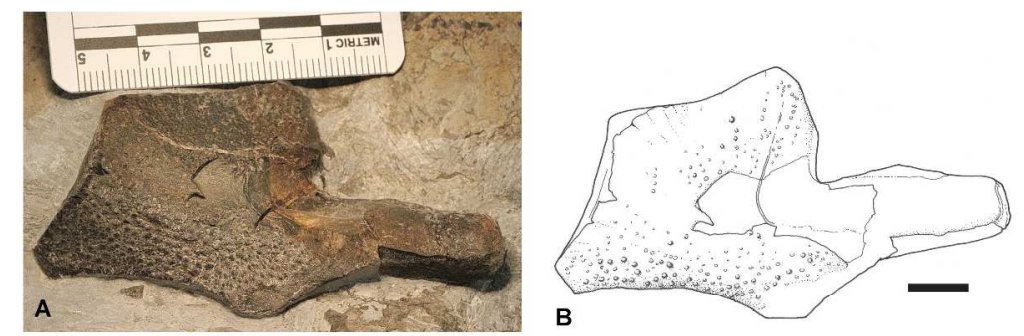

Figure 12.

'Dunkleosteus'; suborbital plate, CMN FV 54827, in lateral view. ioc.so, suborbital portion of infraorbital sensory canal. A. photograph; B. drawing; scale in drawing $=1 \mathrm{~cm}$. Bear Rock Formation, upper Emsian; Anderson River, N.W.T., Canada.

page 21 , after line 491

$279 \times 361 \mathrm{~mm}(300 \times 300 \mathrm{DPI})$ 


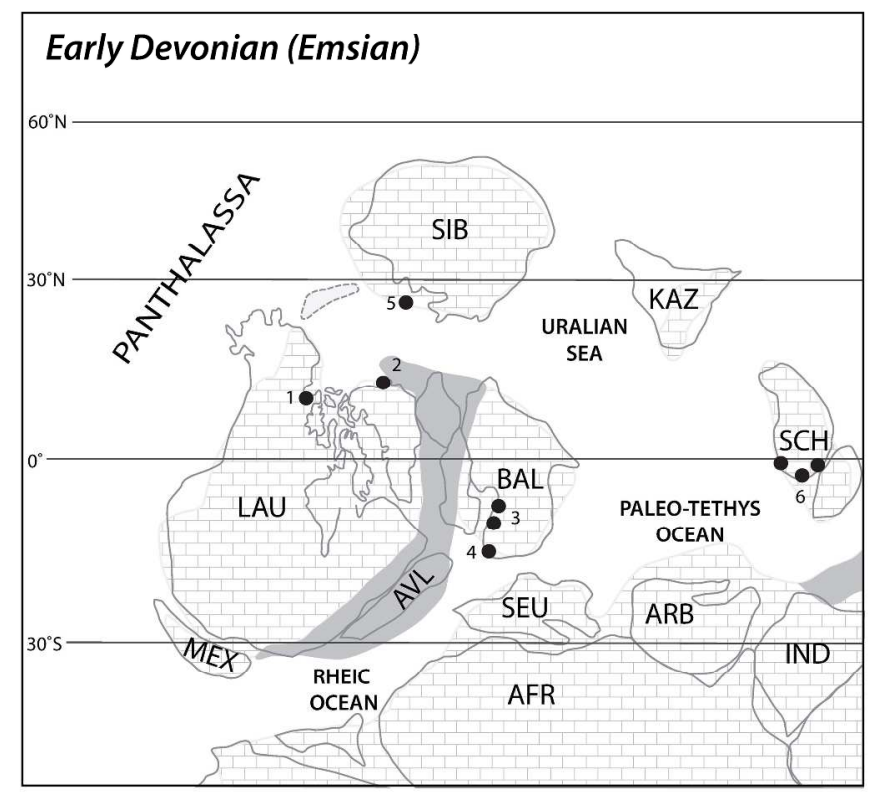

Figure 13.

Early Devonian (late Emsian, c. $395 \mathrm{Ma}$ ) paleogeographic reconstruction, based on Colpron and Nelson (2009, fig. 12). Localities shown as in Table 1: 1- Anderson River, NWT, Canada; 2 - Vestspitsbergen, Svalbard, Norway; 3- Baltic (Lithuania, Poland, Belarus); 4 - Rhenish Slate Massif, Germany; 5 - Kotelny Island, Siberia, Russia; 6 - Beichuan, Sichuan, China and Ludian, Yunnan, China. The possible Heimenia occurrence in northeastern Vietnam is included here with the localities from China. AFR=Africa, $A R B=$ Arabia, $A V L=$ Avalonia, $B A L=$ Baltica, IND=India, $K A Z=K a z a k h s t a n i a, L A U=L a u r e n t i a, M E X=M e x i c o$, $\mathrm{SCH}=$ South China, SEU=Southern Europe, SIB=Siberia. Shaded areas indicate orogenies, including the Appalachians and Caledonides along the medial margins of Laurentia and Baltica. Dashed outline represents possible crustal fragment now submerged in the Arctic Ocean. More recent paleogeographic reconstructions (e.g., Golonka and Gaweda 2012; Domeier and Torsvik 2014) shift the plates farther south, by roughly 15$18^{\circ}$. This suggests a paleolatitude of $5^{\circ}-8^{\circ} \mathrm{S}$ for Locality 1. 
page 27 , after line 617 $279 \times 361 \mathrm{~mm}(300 \times 300 \mathrm{DPI})$ 